\title{
The Lapita Occupation at Naitabale, Moturiki Island, Central Fiji
}

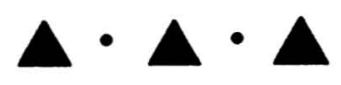

\author{
PATRICK D. NUNN, TOMO ISHIMURA, WILLIAM R. DICKINSON, \\ KAZUMICHI KATAYAMA, FRANK THOMAS, ROSELYN KUMAR, \\ SEPETI MATARARABA, JANET DAVIDSON, \\ AND TREVOR WORTHY
}

DESPITE MORE THAN SO YEARS OF FIELDWORK TARGETING THE EARLIEST (Lapitaera) occupation of southwest Pacific Island archipelagoes and a number of authoritative statements (Kirch 1997; Kirch and Green 2001), many questions remain unanswered regarding this conspicuous and intriguing period of Pacific prehistory. At a regional scale, it is uncertain what precise migratory pathways the Lapita people followed and how rapidly the discovery and colonization of islands took place (Green 2003). Little is known for certain about the watercraft the Lapita people used. In addition, there has been much debate surrounding the lifestyles of the earliest colonists and those who followed them, particularly whether they were "strandloopers" with "a restricted maritime/lagoonal economy" (Groube 1971:312; see also Anderson 2003:76-78) or horticulturalists who selected settlement sites for their potential for growing crops like taro and breadfruit (Green 1979; Kirch 1997).

At a subregional (archipelagic) scale, other questions remain, largely because field research has not yet been able to capture the geographic spread and density of Lapita-era settlements. There is a debate about whether Lapita people preferred smaller islands or whether the apparent observed preference is a function of site visibility; that is, ancient settlements along the coasts of larger, higher islands are more likely to have been obscured by later geomorphological changes (Spriggs 1984; Lepofsky 1988). For some southwest Pacific Island groups, large areas have

Patrick D. Nunn is professor of oceanic geoscience in the School of Geography, University of the South Pacific, Suva, Fiji. Tomo Ishimura is with the Department of Planning and Coordination, National Research Institute for Cultural Properties, Nara, Japan. William R. Dickinson is with the Department of Geosciences, University of Arizona, Tucson. Kazumichi Katayama is with the Laboratory of Physical Anthropology, Graduate School of Science, Kyoto University, Japan. Frank Thomas is with the Pacific Studies Program, Pacific Institute of Advanced Studies, University of the South Pacific, Suva, Fiji. Roselyn Kumar is with the Institute of Applied Sciences, University of the South Pacific, Suva, Fiji. Sepeti Matararaba is with the Department of Prehistory-Archaeology, Fiji Museum, Suva, Fiji. Janet Davidson is editor of the New Zealand Journal of Archaeology, published by the New Zealand Archaeological Association in association with the University of Otago. Trevor Worthy is with Palaeofaunal Surveys, Masterton, New Zealand. 


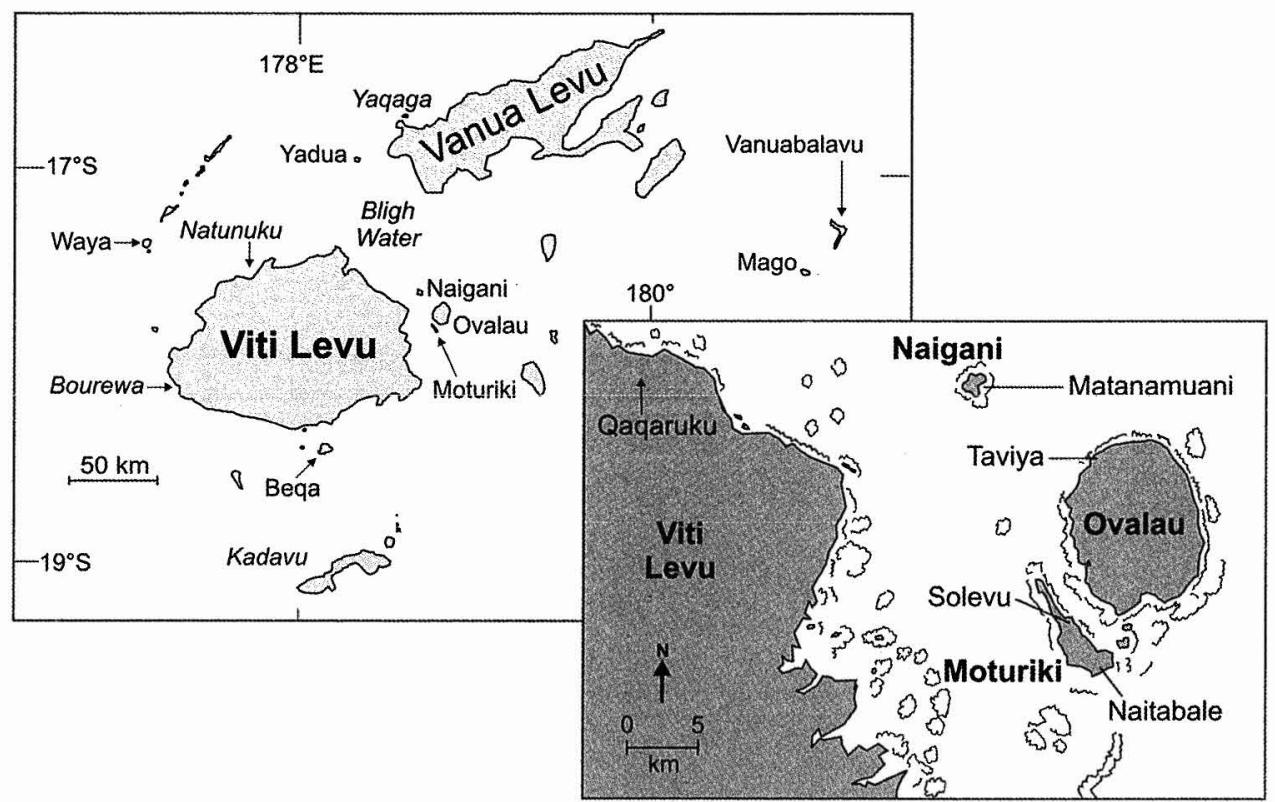

Fig. 1. Map of the principal Fiji Islands showing locations of some key Lapita settlement sites. Inset map shows part of central Fiji with coral reefs and locations of Lapita sites on Moturiki and surrounding islands.

not been examined for traces of Lapita occupation, so conclusions regarding its antiquity and diffusion are tentative (e.g., Vanuatu; Bedford 2003).

For the Fiji Islands (Fig. 1), while there are still areas that have not been investigated, notably Kadavu and Vanua Levu islands, the existence of some 40 Lapita sites, 11 of which have been securely dated, has allowed some cogent statements to be made regarding the time of colonization and the subsequent dispersion of Lapita people through the archipelago (Anderson and Clark 1999; Clark and Anderson 2001; Kumar et al. 2004a; Nunn et al. 2005). At present it seems reasonable to suppose that Lapita people colonized Fiji between 1260 and 970 B.C. (3210-2920 cal. years B.P.), the oldest date (unpublished) from the possible founder site at Bourewa in southwest Viti Levu (Nunn et al. 2004a). This is slightly more than the upper limit of 2900 cal. years B.P. (950 B.C.) suggested by Anderson and Clark (1999) but consistent with the suggestion that the first Lapita people in Fiji arrived about 3000 cal. years B.P. (1050 B.C., Spriggs 2002). The end to Lapita culture in Fiji, as denoted by the end of dentate-stamped pottery production, may have been as early as 2700 cal. years B.P. (750 B.C., Anderson and Clark 1999), following which there was a millennium or so during which only plain (undecorated) pottery of less variable form was manufactured (Burley and Clark 2003).

One of the key areas of Fiji where ideas about the antiquity of Lapita occupation and the preferences of settlers for particular resources and environments has been tested is the central group of islands (see inset, Fig. 1). One of the first Lapita sites described from Fiji, and one that for many years was regarded as the earliest, is at Matanamuani (VL 21/5) on Naigani Island (Best 1981; Anderson and Clark 1999). A plausible corollary to the possibility of the Naigani site being the earliest 
in Fiji is that humans settled the islands of central Fiji before any others, having first passed through the wide, reef-free Bligh Water (see Fig. 1). Dating of the Lapita occupation of Yadua Island (off the west coast of Vanua Levu Island) suggests that this was not the case (Nunn et al. 2005).

As part of an ongoing program of research into the earliest (Lapita-era) human settlements in central Fiji, a team from the University of the South Pacific and the Fiji Museum visited Moturiki Island-15 km south of Naigani-for three weeks in June-July 2002. The results of this fieldwork and associated analyses are described below, followed by a discussion of the implications for early Fiji history.

Fieldwork on Moturiki was directed by Nunn, Kumar, and Matararaba. Analysis of pottery form and motifs was coordinated by Ishimura, with input from Kumar. Bone analysis was conducted by Ishimura, using Kyoto University reference collections, with inputs from Davidson and Worthy. Thomas coordinated shell analyses. Pottery temper analyses were conducted jointly by Dickinson and Kumar. Human skeletal analyses were coordinated by Katayama. Nunn was in overall charge of the project and responsible for study of the area's landscape evolution and the radiocarbon dating of its Lapita occupation.

\section{STUDY AREA}

The island of Moturiki (10.9 $\mathrm{km}^{2}$ in area) is a downfaulted part of the Pliocene volcano Lovoni that comprises the whole of nearby Ovalau Island $\left(102.75 \mathrm{~km}^{2}\right)$. Unlike steep-sided Ovalau, broad coastal plains and fringing reefs have developed around many parts of Moturiki, and it is these attributes that may explain the preference of Lapita people for the latter rather than the former island (Kumar et al. 2004b; Nunn et al. 2004b). Today Moturiki is home to around 700 people organized in ten villages, all along the coast, reflecting a reliance on marine foods similar to that of the island's Lapita inhabitants (Fig. 2).

A single Lapita sherd collected from the beach at Solevu (mistakenly named Saulevu at first) in northern Moturiki in 1999, combined with the likelihood that the Lapita occupation of Naigani Island in the same area was early, led to speculation regarding the importance of the central islands to Lapita colonization of Fiji (Nunn 1999a). In particular, a series of oral traditions from Naigani Island that talked explicitly about a connection between the Lapita site there and that at Solevu was discussed (Ramoli and Nunn 2001), although it has been questioned whether such oral traditions could remain intelligible after some 3000 years (Burley and Clark 2003).

\section{SURVEY AND EXCAVATION}

The 1999 discovery of a Lapita occupation on Moturiki led to the undertaking in 2002 of an extended survey of this island and the northwest coast of nearby Ovalau (see inset, Fig. 1), which is also connected by oral traditions to the Lapita sites on Naigani and at Solevu (Ramoli and Nunn 2001). The team was based in Nasauvuki village and spent the first six days on the island making surface collections of pottery from all coastal flats. Dentate-stamped pottery diagnostic of Lapita occupation was found at Solevu (two pieces) and in the south of the island along the banks of the Mataloaloa River, where it cuts through the coastal flat named 


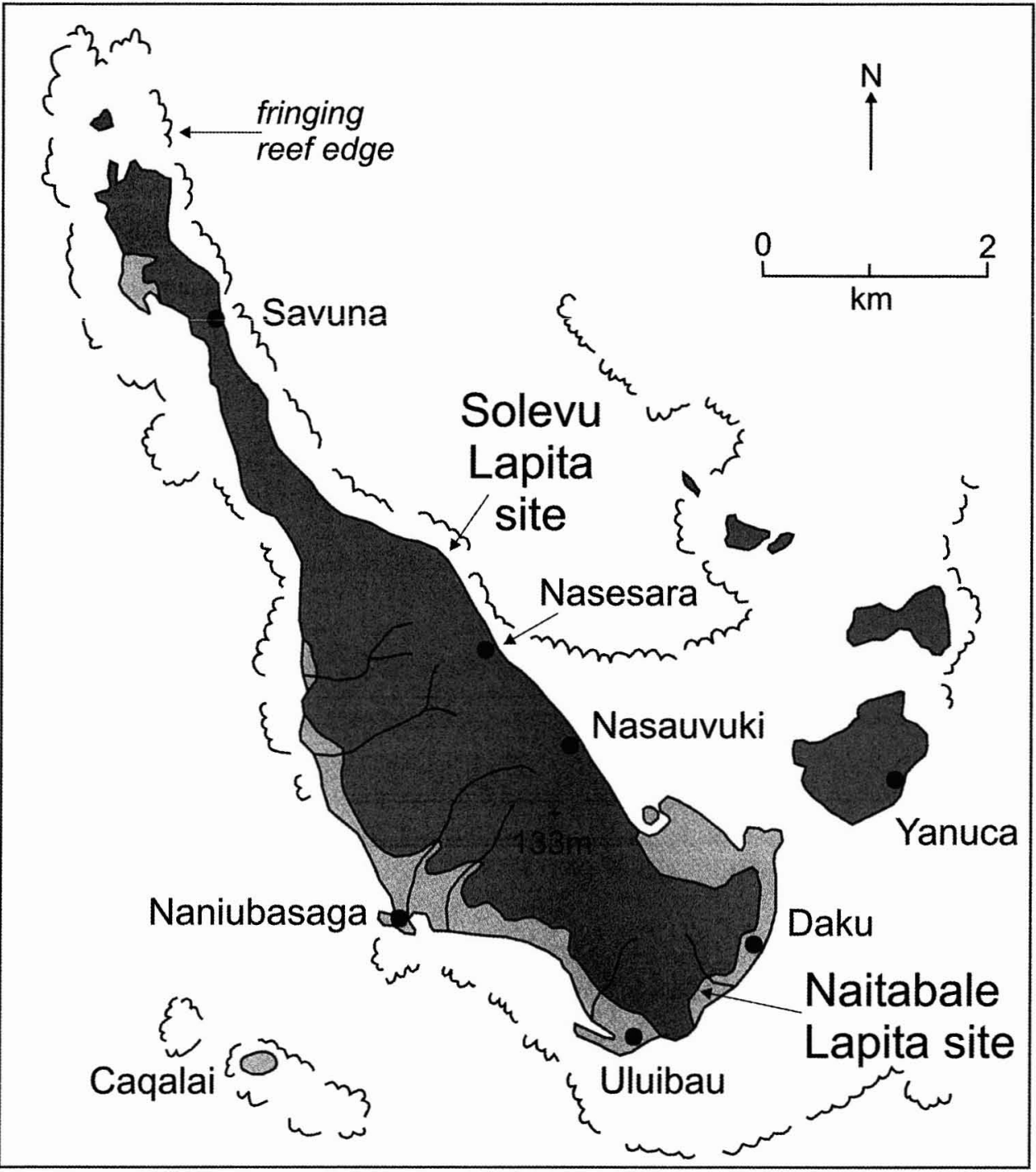

Fig. 2. Moturiki and nearby smaller islands showing the modern villages, the extent of coastal lowland (light shading), and the limits of fringing reefs. Two Lapita sites are known from this area, at Solevu (or Saulevu; Nunn 1999a) and Naitabale (Kumar et al. 2004b; this paper).

Naitabale at a place called Naturuku. A series of 12 dentate-stamped sherds was found through surface collection at Naitabale and proved to be among the most elaborately decorated ever seen by the investigators in Fiji (e.g., see Fig. 6, $n$ 59, 60 , and 82).

After obtaining permission from landowners in nearby Uluibau village, the Naitabale site was excavated. Over a period of two weeks, 13 pits the equivalent of $1 \mathrm{~m}^{2}$ were dug, and all pottery, shells, and bones retained by sieves with a 1.5 $\mathrm{cm}$ mesh were bagged for subsequent analysis. In Pit T1 at a depth of $140 \mathrm{~cm}$, a 
complete human burial was uncovered and, having obtained specific permission to remove it for a limited period of time, the team did so. Following analysis, the skeleton was returned to Moturiki and reburied at the original site of Pit T1 in December 2003.

\section{GEOGRAPHY AND PALAEOGEOGRAPHY}

The Naitabale Lapita site does not possess the range of attractants for Lapita people that Lepfosky (1988) concluded were the main factors in site selection. Naitabale is located along the southeast-facing coast of Moturiki and is fringed by the widest $(400-550 \mathrm{~m})$ reef along the island's coast. It is this single attribute that has probably drawn human settlers to the area from Lapita times to the present; most families in modern Daku and Uluibau villages (see Fig. 2) routinely gather marine foods from this reef today. This area does not have a good anchorage; the coast north of Uluibau, where today boats can anchor 200-300 m offshore, may have been fringed by mangrove forest in Lapita times. Nor is the area particularly attractive for lowland agriculture, with coastal lowland being limited and groundwater often saline. In Lapita times in Fiji (at 950 B.C.), sea level was about $1.45 \mathrm{~m}$ higher than at present, and the area of cultivable lowland around the Naitabale site would have been considerably smaller (Nunn 2005; Nunn and Peltier 2001).

The Naitabale site lies at the mouth of a narrow valley hemmed in by steep cliffs (Fig. 3a). Most of the valley floor appears colluvial rather than alluvial in origin. The site itself is in an area of low relief, comprising undulating beach ridges separated by swales enlarged mostly by rain wash and covered with dense littoral forest. The best exposures of the beach ridges and the human-associated material are along the banks of the Mataloaloa, a low-gradient, intermittent, meandering
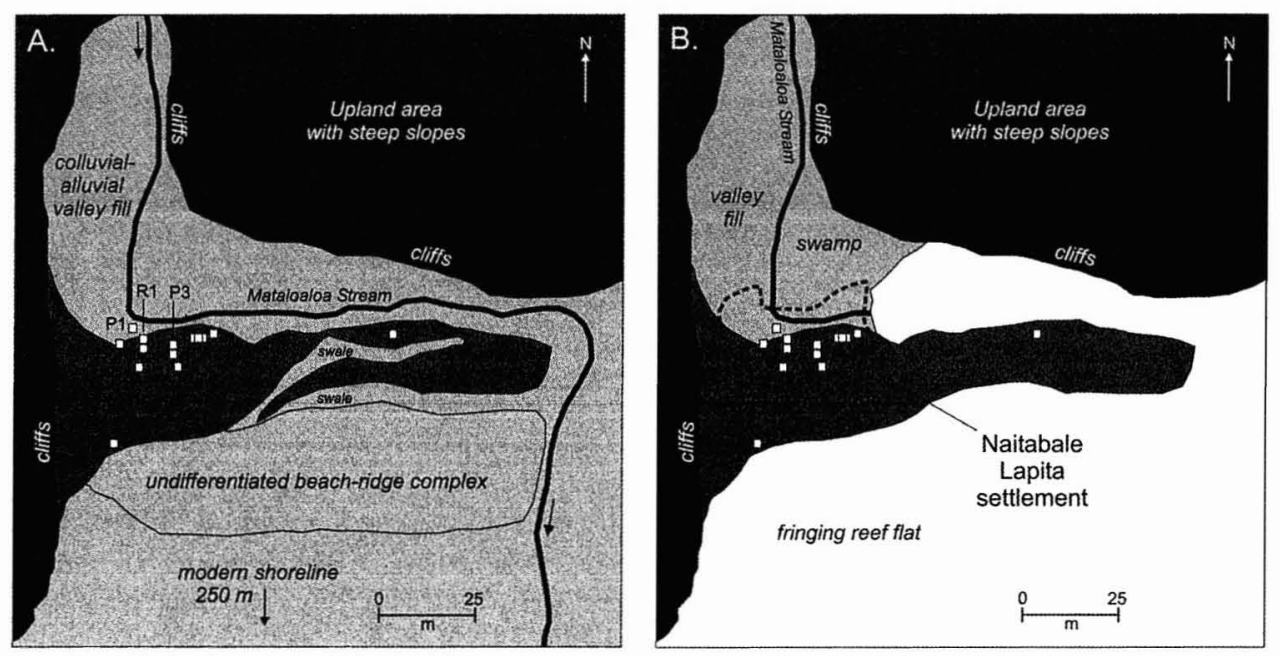

Fig. 3. a: The modern landscape of the Naitabale area showing the location of the pits (sizes exaggerated) excavated on and around the ancient beach ridge (the "Lapita beach ridge"). The entire area is now around $300 \mathrm{~m}$ inland of the present shoreline. b: The landscape of the Naitabale area about 900 B.C. when it was occupied by the Lapita people. The Lapita beach ridge was actively forming and ran eastward into a sand spit. The Lapita settlement, its likely extent shown by the broken line, was in the lee of the beach ridge at the head of a short estuary. 
stream cut to depths of $1.5 \mathrm{~m}$ below average strandplain level in the Naitabale area. It was along the banks and in the bed of the Mataloaloa where most discoveries of Lapita pottery during surface collection were made, and it was here that the first pits were located. Once these pits had been completed, others were located with a view to extending the site in various directions. Lapita sherds collected near or within pits P2 and P4 were not in situ, either being found on the surface or within disturbed layers below. This exercise suggests that the site was about $300 \mathrm{~m}^{2}$ in area, elongate, and stretching for some $30 \mathrm{~m}$ along the inland side of a beach ridge with an original relief of $2-3 \mathrm{~m}$.

At the time of the Lapita occupation, this beach ridge was likely an actively forming beach berm with fringing reef developed along (or just off) its seaward side (Fig. 3b), a clear sign that this reef was likely to have been the main reason for the choice of this settlement. It is envisaged that this beach ridge ran eastward, declining in elevation to form a sand spit at the mouth of the 80-m long estuary of the Lapita-era Mataloaloa. The Lapita site may have spread slightly along the shore at the head of the estuary, although it is envisaged that this area would have been swampy and perhaps fringed by mangrove forest at that time.

Since Lapita times, the net 1.45-m fall of sea level (estimated from Nunn and Peltier 2001) combined with increasing amounts of terrigenous sediments being carried to the shoreline by rivers like the Mataloaloa have led to shoreline straightening and progradation of $250-350 \mathrm{~m}(8-10 \mathrm{~cm} /$ year $)$ along this coast of Moturiki. This progradation took place at the expense of fringing reef. Later occupants of the site generally seem to have lived as close to the shoreline as the Lapita people, meaning that they occupied the lee of the beach ridge closest to the shoreline. In turn, this indicates that the Lapita settlement at Naitabale was not reoccupied by later people for any prolonged period of time, meaning that it is relatively undisturbed. For this reason, almost all the cultural material on the site is likely to be Lapita in age.

Still, it is clear from the stratigraphy and the lack of internal consistency of radiocarbon dates in some pits that some reworking of material has taken place. This is most pronounced along the inland side of the Lapita beach ridge, where fluvial processes are most likely to have been responsible for mixing of various strata. Representative sections are shown in Figures 4 and 5. No cultural features were recognized in any of the pits.

In Pit R2 (Fig. 4a), dentate-stamped pottery was encountered throughout the top $20 \mathrm{~cm}$ and is interpreted as being within sediments redeposited from a location slightly upstream, perhaps during a flood. A second zone of dentate-stamped pottery is found around $60 \mathrm{~cm}$ and, because of the clay in the stratum, is interpreted not as a fluvial deposit but as colluvial, probably slope wash that carried Lapita material downslope from an adjacent location. The in situ Lapita layer in Pit R2 occurs between 105 and $125 \mathrm{~cm}$; the lack of stratigraphic consistency implied by the three charcoal dates is probably a function of old wood having been burned to create the middle sample, although it may also reflect some turbation.

In Pit P3 (Fig. 4b), the sole Lapita layer (indicated by dentate-stamped sherds) is regarded as being in situ, and the stratigraphic inconsistencies implied by the radiocarbon dates are explicable by old wood (see above) and/or turbation. The stratum $(80-156 \mathrm{~cm})$ is interpreted as a fluvial-estuarine deposit, possibly one in which broken pottery and shell refuse were deliberately deposited. 

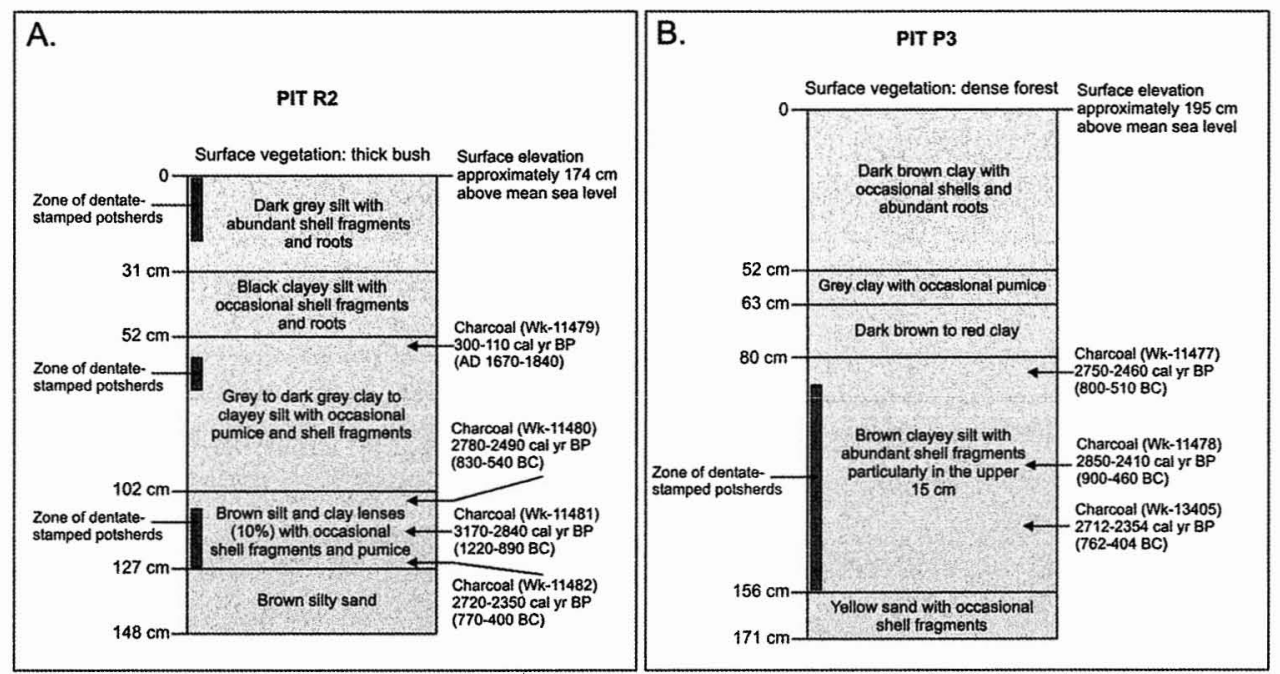

Fig. 4. Stratigraphy of Pits R2 and P3 (see Fig. 3a for locations) at Naitabale, to show the variable degree of reworking in particular pits (like R2) and a relatively undisturbed profile (Pit P3). Full details of radiocarbon dates are given in Table 8 .

Although there was a small number of redeposited Lapita sherds found above the in situ Lapita layer in Pit T1 (Fig. 5), the charcoal dates from this pit are internally consistent and supplemented by dates from or associated with the human skeleton found near the bottom. Pit T1 was part of the Lapita beach ridge, and the sand that forms its lower layers is that deposited by waves during storms,

\section{PIT T1}

Marine shell (Wk-13403) between knees 2803-2658 cal yr BP (853-708 BC)

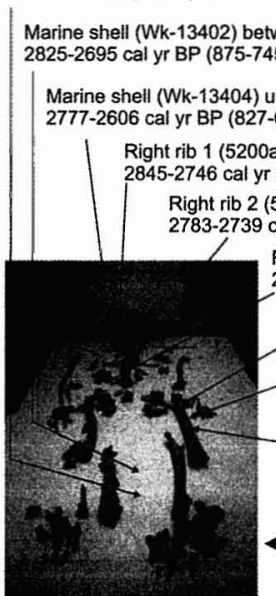

\section{Surface vegetation: light riparian forest}

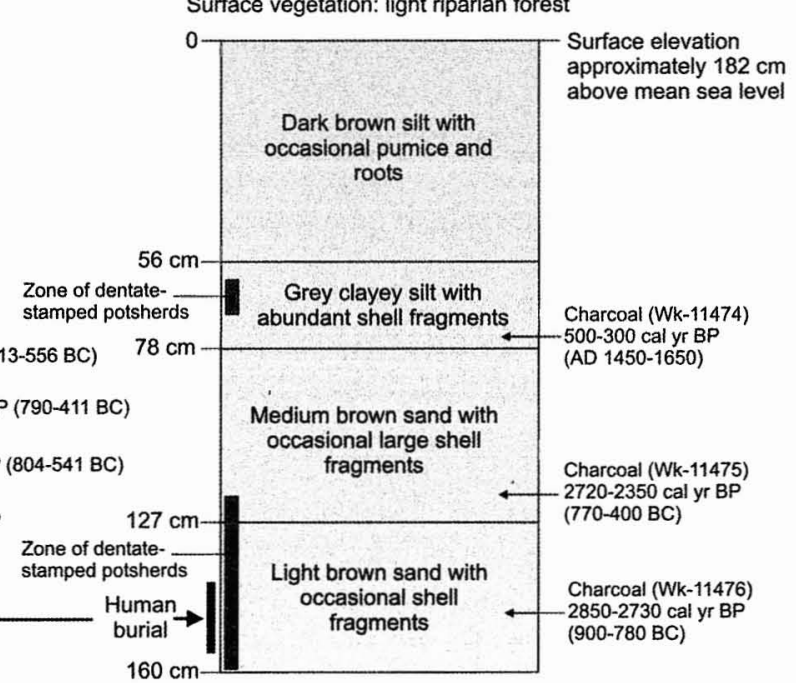

Fig. 5. Stratigraphy of Pit T1 (location in Fig. 3a) to show the position of the human burial and the various dates obtained. Full details of radiocarbon dates (ranges are $2 \sigma$ ) are given in Table 8. 
Table i. Distribution, Motif Classification, and Decoration Type OF THE 92 LAPITA SHerdS

\begin{tabular}{|c|c|c|c|c|c|}
\hline No. & LOCATION & $\begin{array}{c}\text { DEPTH } \\
\text { (CM) }\end{array}$ & MOTIFS & $\begin{array}{c}\text { TYPE OF } \\
\text { DECORATION }\end{array}$ & $\begin{array}{c}\text { TEMPER } \\
\text { TYPE }\end{array}$ \\
\hline 1 & $\mathrm{P} 1$ & $0-10$ & - & dentate & quartzose \\
\hline 2 & & $0-10$ & n.d.+M436 & dentate & feldspathic \\
\hline 3 & & $0-10$ & M446 & dentate & standard \\
\hline 4 & & $10-20$ & $\mathrm{M} 1+\mathrm{M} 436$ & dentate & feldspathic \\
\hline 5 & & $10-20$ & M175 & dentate & standard \\
\hline 6 & & $20-30$ & - & dentate & standard \\
\hline 7 & & $20-30$ & M155 & dentate & placer \\
\hline 8 & & $70-80$ & - & dentate & \\
\hline 9 & & $70-80$ & n.d. & dentate & \\
\hline 10 & P2 & $30-40$ & $\mathrm{M} 208+\mathrm{M} 123$ & dentate & quartzose \\
\hline 11 & P3 & $80-90$ & M162 & dentate & \\
\hline 12 & & $90-100$ & M441 & dentate & \\
\hline 13 & & $100-110$ & 一 & dentate & feldspathic \\
\hline 14 & & $110-120$ & 一 & dentate & \\
\hline 15 & & $110-120$ & M449 & dentate & placer \\
\hline 16 & & $110-120$ & n.d. & dentate & \\
\hline 17 & & $120-130$ & M268 & dentate & standard \\
\hline 18 & & $120-130$ & M438 & dentate & standard \\
\hline 19 & & $120-130$ & - & dentate & standard \\
\hline 20 & & $130-140$ & $\mathrm{M} 436+\mathrm{M} 35$ & dentate & quartzose \\
\hline 21 & & $130-140$ & M436 & dentate & standard \\
\hline 22 & & $140-150$ & M436 & dentate & standard \\
\hline 23 & & $140-150$ & n.d. & dentate & placer \\
\hline 24 & & $140-150$ & - & dentate & standard \\
\hline 25 & & $140-150$ & M254 & dentate & feldspathic \\
\hline 26 & & $150-160$ & - & dentate & \\
\hline 27 & & $150-160$ & - & dentate & \\
\hline 28 & & $150-160$ & M441 & dentate & \\
\hline 29 & & $160-170$ & M441 & dentate & \\
\hline 30 & & $160-170$ & M326 & dentate & \\
\hline 31 & & $110-120$ & M230 & incised & \\
\hline 32 & P5 & $80-90$ & - & dentate & \\
\hline 33 & & $120-130$ & - & dentate & \\
\hline 34 & & $130-140$ & n.d. & dentate & standard \\
\hline 35 & & $130-140$ & n.d. & dentate & \\
\hline 36 & & $130-140$ & n.d. & dentate & \\
\hline 37 & R1 & $40-50$ & M268 & dentate & \\
\hline 38 & & $0-50$ & n.d. & dentate & \\
\hline 39 & & $40-50$ & M207 & dentate & standard \\
\hline 40 & & $50-60$ & M428 & dentate & standard \\
\hline 41 & & $70-80$ & n.d. & dentate & \\
\hline 42 & & $100-110$ & M254 & dentate & standard \\
\hline 43 & & $80-90$ & - & dentate & \\
\hline 44 & & $100-110$ & - & dentate & \\
\hline 45 & & $100-110$ & n.d. & dentate & standard \\
\hline 46 & & $100-110$ & M378 & dentate & quartzose \\
\hline 47 & & $110-120$ & - & dentate & standard \\
\hline 48 & & $120-130$ & n.d. & dentate & standard \\
\hline 49 & & $40-50$ & M158 & incised & \\
\hline 50 & & $0-50$ & n.d. & incised & \\
\hline
\end{tabular}


TABle I (Continued)

\begin{tabular}{|c|c|c|c|c|c|}
\hline NO. & LOCATION & $\begin{array}{c}\text { DEPTH } \\
(\mathrm{CM})\end{array}$ & MOTIFS & $\begin{array}{c}\text { TYPE OF } \\
\text { DECORATION }\end{array}$ & $\begin{array}{l}\text { TEMPER } \\
\text { TYPE }\end{array}$ \\
\hline 51 & & $90-100$ & M230 & incised & \\
\hline 52 & R2 & $0-10$ & - & dentate & standard \\
\hline 53 & & $0-10$ & - & dentate & \\
\hline 54 & & $10-20$ & - & dentate & quartzose \\
\hline 55 & & $40-50$ & M234 & dentate & \\
\hline 56 & & $60-70$ & n.d. & dentate & standard \\
\hline 57 & & $60-70$ & - & dentate & standard \\
\hline 58 & & $100-110$ & M346? & dentate & standard \\
\hline 59 & & $110-120$ & M147 & dentate & standard \\
\hline 60 & & $110-120$ & M43+n.d. & dentate & standard \\
\hline 61 & & $110-120$ & n.d. & dentate & standard \\
\hline 62 & & $120-130$ & M53+M303 & dentate & standard \\
\hline 63 & & $130-140$ & M90 & dentate & standard \\
\hline 64 & R3 & $40-50$ & M436 & dentate & \\
\hline 65 & & $40-50$ & M207 & dentate & \\
\hline 66 & & $90-100$ & - & dentate & \\
\hline 67 & & $110-120$ & M207 & dentate & standard \\
\hline 68 & $\mathrm{~T} 1$ & $60-70$ & M207+M345? & dentate & feldspathic \\
\hline 69 & & $120-130$ & M175 & dentate & standard \\
\hline 70 & & $120-130$ & M436? & dentate & standard \\
\hline 71 & & $130-140$ & M154 & dentate & standard \\
\hline 72 & & $130-140$ & M260 & dentate & standard \\
\hline 73 & & $130-140$ & - & dentate & standard \\
\hline 74 & & $140-150$ & - & dentate & standard \\
\hline 75 & & $140-150$ & - & dentate & \\
\hline 76 & & $0-100$ & M187 & incised & \\
\hline 77 & & $0-100$ & M436 & incised & \\
\hline 78 & $\mathrm{~T} 2$ & $10-20$ & M319 & incised & \\
\hline 79 & surface collection & & M215+M162 & dentate & \\
\hline 80 & surface collection & & M300 & dentate & \\
\hline 81 & surface collection & & M363 & dentate & \\
\hline 82 & surface collection & & M302 & dentate & \\
\hline 83 & surface collection & & $\mathrm{M} 213+\mathrm{M} 405+\mathrm{M} 18$ & dentate & \\
\hline 84 & surface collection & & - & dentate & \\
\hline 85 & surface collection & & M300 & dentate & \\
\hline 86 & surface collection & & n.d. & dentate & \\
\hline 87 & surface collection & & M429 & dentate & \\
\hline 88 & surface collection & & M295 & dentate & \\
\hline 89 & surface collection & & M1 & dentate & \\
\hline 90 & surface collection & & - & dentate & \\
\hline 91 & surface collection & & n.d. & incised & \\
\hline 92 & surface collection & & M431 & incised & \\
\hline
\end{tabular}

Note: Motifs are according to the system of Anson (1983); a dash is shown where no motif could be identified.

usually on its ocean-facing side but also washed or blown over the top at the time or under calmer conditions subsequently. Dates (see Table 8) are presented and discussed in a separate section below.

The following sections report the results of the analyses on the various materials excavated and their significance. 


\section{RESULTS AND INTERPRETATION}

\section{Pottery}

Some 17,160 potsherds were collected from Naitabale through undiscriminating surface collection and excavation. Of this total, 92 sherds $(0.5$ percent) were either dentate-stamped Lapita or Lapita-incised ware (Table 1). Selected Lapita sherds are shown in Figure 6. Comparisons with other Lapita sites are indicated in Tables 2 and 3.

Pottery Decoration - Using Anson's (1983) inventory of Lapita decorative motifs, it seems that the Naitabale Lapita sherds generally have a greater affinity with Western Lapita rather than the Eastern Lapita Province where the site is located (see Table 2). The existence of face designs on many Lapita sherds from Naitabale also attests to the site's antiquity within the Eastern Lapita Province, where face designs are rare (Spriggs 1990). Plausible reconstructions of selected designs from Naitabale are shown in Figures 7-9.

In Spriggs' (1990) classification, 86 and 61 (see Fig. 7) are categorized as Type $2 \mathrm{C}$, distinguished by long noses and medallions, a face motif common in the Far Western (Kirch 1988) and Western Lapita (Spriggs 1990) Provinces. A comparative example from New Caledonia is shown in Figure 7. Another face design from Naitabale (68 in Fig. 7) is believed to be a later type of alternating eyenose-eye, where each eye is shared between two faces. As shown in Figure 7, this was also found at the Naigani Lapita site in central Fiji and evolved into more abstract forms in Vanuatu and New Caledonia.

Some of the elaborate, complex designs found on Naitabale Lapita sherds are shown in Figure 8 . The design on sherd 87 is part of the labyrinth motif widely distributed in Far Western and Western Lapita, particularly in New Caledonia (Sand 1997). A simpler type of labyrinth motif, formed from a combination of repeated crescentic and angular patterns, has also been found in the Solomon Islands (Fig. 8).

Finally, there are Lapita-incised designs among the Naitabale collection. Table 3 shows the percentages of the incised pottery in various assemblages, indicating that incised pottery is abundant in Western Lapita and generally rare in Eastern Lapita, except at Naigani. In Figure 9, the combination of curves and triangles in sherd 49 are similar to incised designs from New Caledonia; a comparable situation is likely for the obliquely converging lines in sherd 50 (Sand 1998). The incised lattice motif, also common in dentate, has been found in the Solomon Islands (Donovan 1973). The other incised designs shown in Figure 9 are fairly common, with the exception of the spiral design on sherd 91 that appears to be unique to Naitabale.

On the basis of motif analysis, the Lapita pottery from Naitabale shows close affinities with assemblages in the Western Lapita Province, notably New Caledonia (WKO013A) (Sand 1998) and the Solomon Islands (RF-2) (Donovan 1973). It also has much in common with the assemblages from the Lapita site at Matanamuani on Naigani Island, $20 \mathrm{~km}$ distant (Best 1981, 2002). On the basis of this and the radiocarbon dating of the Naitabale Lapita occupation (see below), which may well be earlier than the suggested 2900 B.P. date for colonization of Fiji (Anderson and Clark 1999), it is considered that the Naitabale pottery belongs to the "Middle Lapita" rather than the "Later Lapita" period (Summerhayes 2000). 
A.

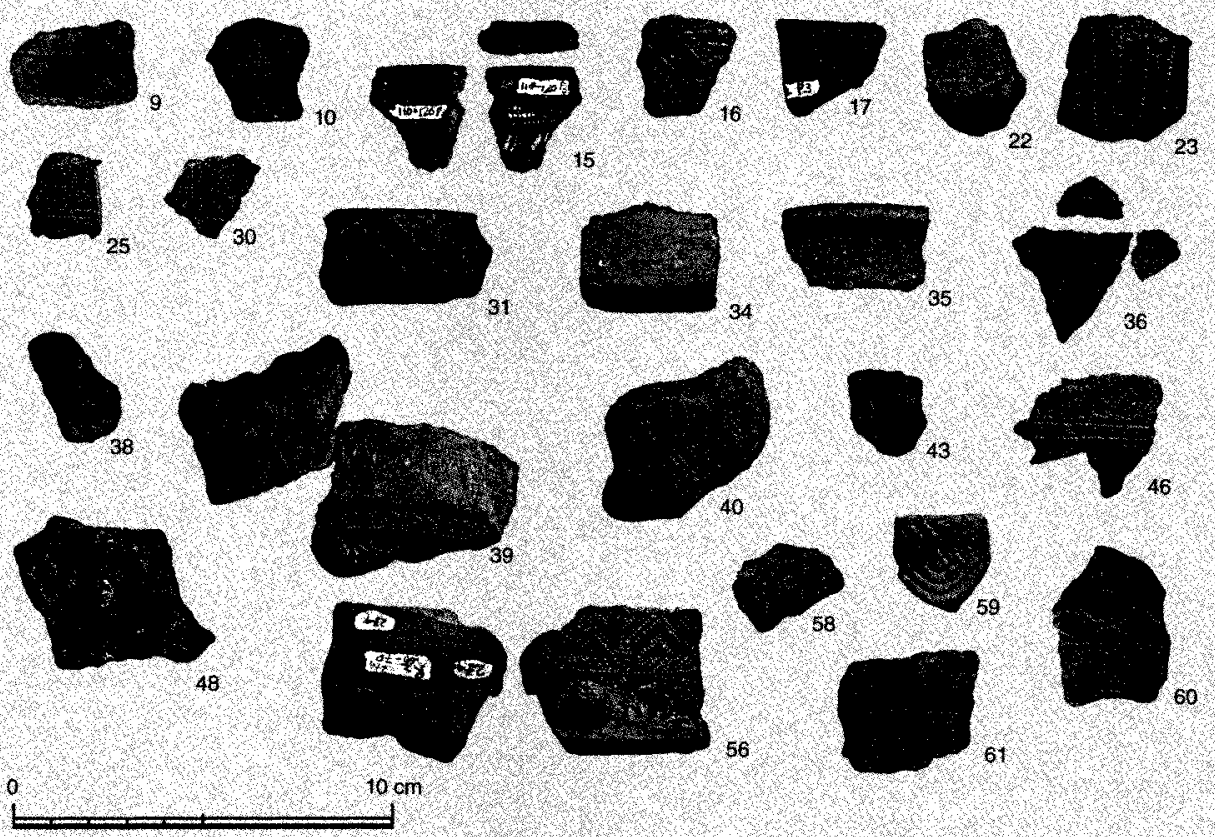

B.
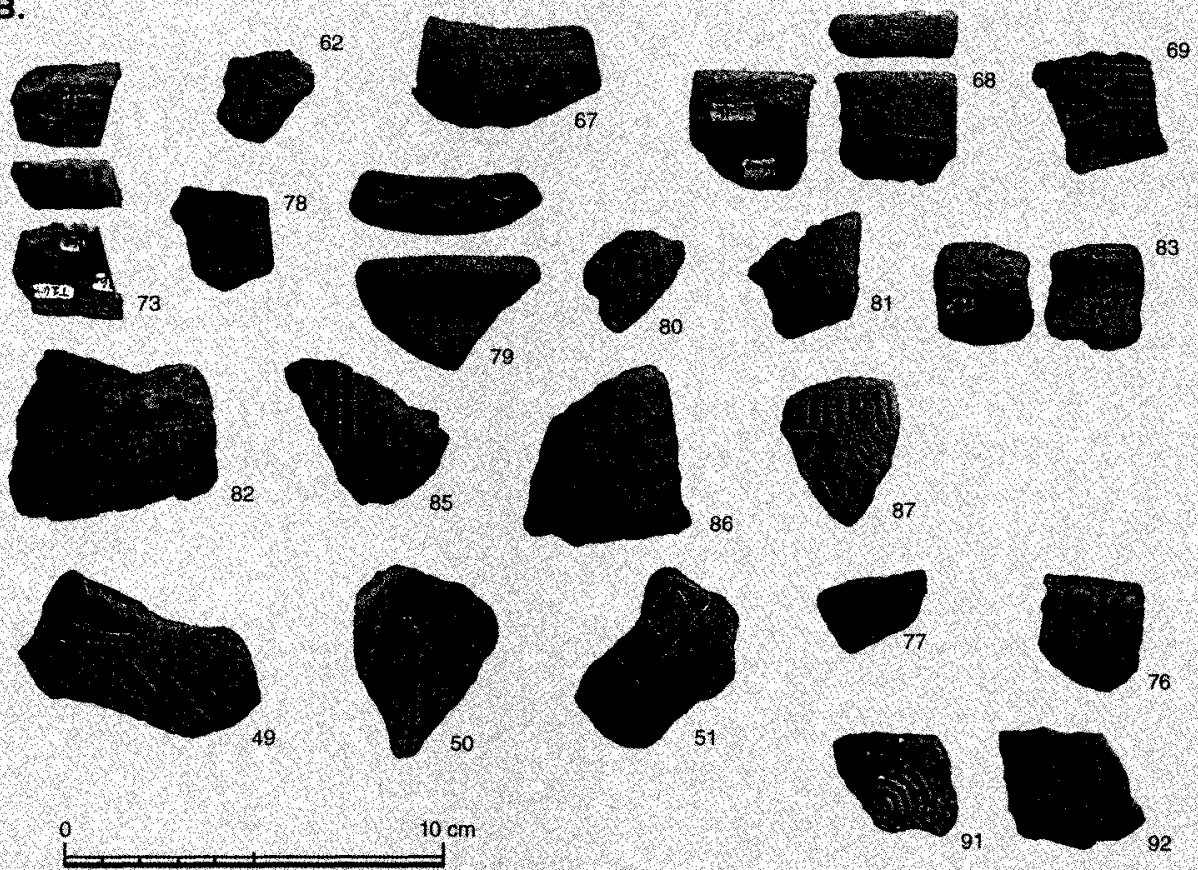

Fig. 6. Photographs of selected Lapita sherds from Naitabale. See Table 1 for details of places of collection, motif, and decoration. 
Pottery Sourcing through Temper Analysis - The use of petrographic analysis for characterizing and sourcing the sand components (tempers) of Lapita and other pottery in the Pacific Islands has become well established (Dickinson 2001). A major conclusion is that most of the pottery made during Pacific prehistory was manufactured locally. Yet in particular assemblages there are often low proportions of exotic sherds for which temper analysis has been used to help determine ancient trade or migration routes (Burley et al. 2001; Dickinson 2001; Dickinson et al. 1996; Ladefoged et al. 1998). To this end, 45 dentate-stamped sherds from the Naitabale Lapita site were thin-sectioned and subjected to temper analysis. Tempers were found to fall into four genetic groups: standard, quartzose, feldspathic, and placer (see Table 1).

Standard tempers are most abundant (71 percent), being derived from volcanic placer sands containing both pyroxene and hornblende. These tempers are considered indigenous to Moturiki or nearby Ovalau. They occur at all depth levels in all pits, bar one. Raw data for sherds having the standard temper type are listed in Table 4, the key determinant of their standard classification being the pyroxene/hornblende ratio calculated in the column at far right $(0.76 \pm 0.1)$.

Quartzose tempers (11 percent) come half from shallow levels $(<20 \mathrm{~cm})$ and half from deep levels $(>110 \mathrm{~cm})$. These tempers generically resemble the dissected orogen temper type of the Rewa Delta and are accordingly inferred to represent ceramic transfer from southeast Viti Levu to Moturiki (approximately $25 \mathrm{~km}$ away).

Feldspathic tempers (11 percent) derive from plagioclase-rich sands containing biotite-mica flakes and oxyhornblende. They probably represent ceramic transfer to Moturiki from Kadavu (150 km away), because biotite is unknown and oxyhornblende is rare in all tempers from elsewhere in Fiji.

Placer tempers ( 7 percent) are strongly placered and hornblende free (or nearly so), possibly representing ceramic transfer to Moturiki from Lau (230 km away). Three of the four sherds with placer tempers come from in situ deposits more than $1 \mathrm{~m}$ below the ground surface (see Table 1), suggesting that this comparatively long-distance transfer was a defining characteristic of the earliest Lapita occupation at Naitabale.

As at most Lapita sites, the most abundant sherds contain indigenous (or standard) tempers. As Moturiki is an outlier of the Lovoni (Ovalau) volcano, geologi$\mathrm{cal}$ arguments are unable to distinguish temper sands from the two islands. Other tempers cannot have originated on either Moturiki or Ovalau but instead may represent ceramic (or temper-sand) transfer from southeast Viti Levu, Kadavu, and Lau (Fig. 10). Given the early age of the Naitabale ceramic assemblage (see below), perhaps the most important insights gained from temper analysis are appreciation that the earliest Lapita occupants of Fiji had already established (or still maintained) a network of overwater contacts within Fiji and that other comparably ancient Lapita sites must exist within Fiji despite the general lack of archaeological documentation to date. In addition, the sherds interpreted to derive from Kadavu make the point, not for the first time (Nunn 1999b), that important Lapita-era ceramic sites are likely to be present somewhere on this island, even though none have yet been found. 
Table 2. Geographical Distribution of the Motifs Found at Naitabale

\begin{tabular}{|c|c|c|c|c|c|c|c|c|c|c|c|c|c|c|c|c|c|c|c|c|c|}
\hline & \multicolumn{10}{|c|}{ FAR WESTERN LAPITA } & \multicolumn{7}{|c|}{ WESTERN LAPITA } & \multicolumn{4}{|c|}{ EASTERN LAPITA } \\
\hline & WATOM & AMBITLE & TALASEA & ELOAUA & $\begin{array}{c}\text { FOH } \\
\text { SQ. DEF }\end{array}$ & $\begin{array}{c}\text { FOG } \\
\text { SQ. G }\end{array}$ & $\mathrm{FNY}$ & FOJ & FSZ & FNT & $\mathrm{RF}-2$ & $\mathrm{RF}-6$ & sz-8 & SZ-48 & WKOOI 3A & VATCHA & MALO & YANUCA & NATUNUKU & NAIGANI & $\begin{array}{l}\text { TONGA } \\
\text { TO. } I-6\end{array}$ \\
\hline M1 & $\mathrm{X}$ & $\mathrm{x}$ & $\mathrm{x}$ & & $\mathrm{x}$ & & $\mathrm{x}$ & $\mathrm{x}$ & $\mathrm{X}$ & & $\mathrm{x}$ & & $\mathrm{x}$ & $\mathrm{X}$ & & $\mathrm{x}$ & $\mathrm{X}$ & $\mathrm{x}$ & $\mathrm{x}$ & $\mathrm{x}$ & $\mathrm{x}$ \\
\hline M18 & $\mathrm{X}$ & $\mathrm{x}$ & & & & & & & & & $\mathrm{X}$ & $\mathrm{X}$ & $\mathrm{X}$ & $\mathrm{X}$ & & $\mathrm{x}$ & & $\mathrm{x}$ & $\mathrm{x}$ & & $\mathrm{x}$ \\
\hline M35 & $\mathrm{X}$ & & & & $\mathrm{X}$ & $\mathrm{X}$ & $\mathrm{x}$ & & $\mathrm{X}$ & $\mathrm{X}$ & & & & & & $\mathrm{X}$ & $\mathrm{X}$ & $\mathrm{x}$ & $\mathrm{X}$ & & $\mathrm{X}$ \\
\hline M43 & & $\mathrm{x}$ & & & & & & & & & & & $\mathrm{X}$ & $\mathrm{x}$ & & $\mathrm{X}$ & $\mathrm{X}$ & & & & \\
\hline M53 & $\mathrm{X}$ & $\mathrm{x}$ & & & & & $\mathrm{x}$ & $\mathrm{X}$ & & & $\mathrm{X}$ & $\mathrm{X}$ & $\mathrm{X}$ & $\mathrm{x}$ & $\mathrm{X}$ & $\mathrm{x}$ & $\mathrm{X}$ & $\mathrm{X}$ & $\mathrm{X}$ & & \\
\hline M90 & & & & & & & & & & & & & & & $\mathrm{X}$ & $\mathrm{X}$ & & & & & \\
\hline M123 & & & & & & & & & & & & & & & & & & $\mathrm{x}$ & $\mathrm{x}$ & & $\mathrm{x}$ \\
\hline M147 & & & & & & & & & & & & & & & & & $\mathrm{X}$ & & & & \\
\hline M154 & & & & & & & & & & & & & & & & & & $\mathrm{x}$ & & & \\
\hline M155 & & & & & & & & & & & & & & & & & & $\mathrm{x}$ & $\mathrm{X}$ & & \\
\hline M158 & & & & & & & & & & & $\mathrm{X}$ & & & & & & & & & & $\mathrm{X}$ \\
\hline M162 & $\mathrm{X}$ & $\mathrm{X}$ & & & & & & & & & & & $\mathrm{X}$ & & & & & & & $\mathrm{X}$ & $\mathrm{x}$ \\
\hline M164 & & & & & $\mathrm{X}$ & & & & & & & & & & & & $\mathrm{X}$ & & & & $\mathrm{x}$ \\
\hline M175 & & & & & & & & & & & & & & & & & & $\mathrm{x}$ & & & \\
\hline M187 & & & & & & & & & & & $\mathrm{x}$ & $\mathrm{X}$ & $\mathrm{x}$ & & & $\mathrm{X}$ & & $\mathrm{X}$ & & $\mathrm{X}$ & $\mathrm{X}$ \\
\hline M207 & $\mathrm{X}$ & $\mathrm{X}$ & & & & & $\mathrm{X}$ & $\mathrm{X}$ & & $\mathrm{X}$ & $\mathrm{X}$ & $\mathrm{X}$ & $\mathrm{X}$ & & $\mathrm{X}$ & $\mathrm{x}$ & $\mathrm{X}$ & $\mathrm{X}$ & & $\mathrm{x}$ & $\mathrm{x}$ \\
\hline M208 & & $\mathrm{X}$ & & & $\mathrm{X}$ & & $x$ & & & & & & & & & & & & & & $\mathrm{x}$ \\
\hline M213 & & & & & & & & & & & $\mathrm{X}$ & & $\mathrm{X}$ & $\mathrm{X}$ & $\mathrm{X}$ & $\mathrm{X}$ & & & & & \\
\hline M215 & & & & & & & & & & & & & & & $\mathrm{x}$ & $\mathrm{x}$ & & & & & \\
\hline M230 & $\mathrm{X}$ & & & & & & $\mathrm{X}$ & & & & & & $\mathrm{X}$ & & & $\mathrm{x}$ & & $\mathrm{X}$ & $\mathrm{x}$ & $\mathrm{X}$ & $\mathrm{X}$ \\
\hline M234 & & & & & $\mathrm{X}$ & & & & & & $\mathrm{x}$ & & & & & & & & & & \\
\hline M254 & & & & & & & & & & & & & & & $\mathrm{X}$ & $\mathrm{x}$ & & & & & \\
\hline M260 & & $\mathrm{X}$ & $\mathrm{X}$ & & & & & & & & $\mathrm{X}$ & $\mathrm{X}$ & $\mathrm{x}$ & $\mathrm{x}$ & & $\mathrm{x}$ & & & & $\mathrm{x}$ & $\mathrm{X}$ \\
\hline M267 & & & & & & & & & & & & & & & & & $\mathrm{x}$ & $\mathrm{X}$ & & & \\
\hline M268 & & & & & $\mathrm{X}$ & $\mathrm{X}$ & & & & & & & & & & & $\mathrm{x}$ & $\mathrm{X}$ & & & \\
\hline M295 & & & & & & & & & & & & & & & & & & & $\mathrm{x}$ & & \\
\hline M300 & & & & & & & & & & & & & & & & & & & $x$ & & \\
\hline M302 & & & & & & & & & & & & & & & & & & & $\mathrm{X}$ & & \\
\hline M303 & & & & & & & & & & & & & & & & $\mathrm{X}$ & & & $\mathrm{X}$ & & \\
\hline M319 & & & & & & & & & & & & & & & & & & & $\mathrm{X}$ & & $\mathrm{X}$ \\
\hline M326 & & & & & & & & & & & & & & & & & & $\mathrm{x}$ & & & \\
\hline
\end{tabular}




\begin{tabular}{|c|c|c|c|c|c|c|c|c|c|c|c|c|c|c|c|c|c|c|c|c|c|}
\hline M345 & $\mathrm{X}$ & & & & & & $\mathrm{X}$ & & & & & & & & & & & & & & \\
\hline M346 & & & & & & & & & & & & & & & $\mathrm{X}$ & & & & & & \\
\hline M363 & & & & & & & & & & & & & & & $x$ & $\mathrm{X}$ & & & & & $\mathrm{X}$ \\
\hline M378 & $\mathrm{X}$ & & & & & & & & & & $\mathrm{X}$ & & & & & $\mathrm{X}$ & & & & & \\
\hline M405 & & & & & & & & & & & $\mathrm{X}$ & & & & & & & & & & \\
\hline M428 & & & & & & & & & & & $\mathrm{X}$ & & & & & & & & & & \\
\hline M429 & $\mathrm{X}$ & & & & & & & & & & & & & & $\mathrm{X}$ & $\mathrm{X}$ & & & & & \\
\hline M431 & & & & & & & & & & & $\mathrm{X}$ & & & & & & & & & & \\
\hline M436 & & & & & & $\mathrm{X}$ & & & & & $\mathrm{X}$ & & & & & & $\mathrm{X}$ & & & $\mathrm{X}$ & $\mathrm{X}$ \\
\hline M438 & & & & & & & & & & & & & & & & & $\mathrm{X}$ & & & & $\mathrm{X}$ \\
\hline M441 & $\mathrm{X}$ & & & & $x$ & & & $X$ & & & $X$ & $\mathrm{X}$ & $X$ & $X$ & $\mathrm{X}$ & $X$ & & & & & $\mathrm{X}$ \\
\hline M446 & & & & & & & & & & & & & & & & $\mathrm{X}$ & & & & & \\
\hline M449 & & & & & & & & & & & & & & $\mathrm{X}$ & & & & & & & \\
\hline $\begin{array}{l}\text { No. of } \\
\text { shared } \\
\text { motifs }\end{array}$ & 11 & 8 & 2 & 0 & 7 & 3 & 7 & 4 & 2 & 2 & 15 & 6 & 11 & 8 & 10 & 19 & 11 & 14 & 12 & 7 & 17 \\
\hline
\end{tabular}




\begin{tabular}{|c|c|c|c|c|c|c|c|c|}
\hline PROVINCE & SITE & & & & DENTATE & INCISED & $\begin{array}{l}\text { PADDLE } \\
\text { IMPRESSED }\end{array}$ & $\mathrm{N}=$ \\
\hline \multirow[t]{5}{*}{ Far Western } & $\begin{array}{l}\text { Talepakemalai area B (C3), Bismarck Archipelago, } \\
\text { Papua New Guinea }\end{array}$ & & & & 10.5 & 0.5 & & ? \\
\hline & $\begin{array}{l}\text { Talepakemalai area B (C1), Bismarck Archipelago, } \\
\text { Papua New Guinea }\end{array}$ & & & & 9.0 & 7.0 & & ? \\
\hline & Adwe (unit A-B), Arawe Islands, Papua New Guinea & & & & 4.2 & 0.4 & & 3617 \\
\hline & Adwe (unit C-D), Arawe Islands, Papua New Guinea & & & & 3.0 & 0.7 & & 4076 \\
\hline & Apalo, Arawe Islands, Papua New Guinea & & & & 1.5 & 2.7 & & 6998 \\
\hline \multirow[t]{5}{*}{ Western } & Nanggu (SZ-8), Santa Cruz Islands, Solomon Islands & & & & 61.9 & 27.5 & & 3654 \\
\hline & Nenumbo (RF-2), Santa Cruz Islands, Solomon Islands & & & & 54.9 & 29.9 & & 4545 \\
\hline & Ngamanie (RF-6), Santa Cruz Islands, Solomon Islands & & & & 61.3 & 18.1 & & 1549 \\
\hline & Vatcha (Layer IV), Île des Pins, New Caledonia & & & & 26.7 & 5.5 & 0.7 & 438 \\
\hline & Vatcha (Layer II), Île des Pins, New Caledonia & & & & 30.7 & 7.9 & 2.3 & 215 \\
\hline \multirow[t]{15}{*}{ Eastern } & Matanamuani, Naigani Island, Fiji & & & & 33.0 & 27.9 & 0.7 & 2937 \\
\hline & Natunuku (Layer 6), Viti Levu Island, Fiji & & & & 22.3 & 0.5 & 0.5 & 373 \\
\hline & Yanuca (Layer 3), Viti Levu Island, Fiji & & & & 6.5 & 0.0 & 3.2 & 2510 \\
\hline & Nukuleka, Tongatapu Island, Tonga & & & & 9.1 & 0.8 & & 4087 \\
\hline & Ha'ateiho, Tongatapu Island, Tonga & & & & 1.5 & 0.4 & & 11,153 \\
\hline & Naitabale, Moturiki Island, Fiji & & & & 0.5 & 0.1 & & 17,160 \\
\hline & & Total (all & $\mathbf{R} 1$ & $(90-100)$ & 0.0 & 1.0 & & 101 \\
\hline & & excavated & & $(100-110)$ & 6.6 & 0.0 & & 61 \\
\hline & & units) & & $(110-120)$ & 3.8 & 0.0 & & 26 \\
\hline & & & & $(120-130)$ & 11.1 & 0.0 & & 9 \\
\hline & & & & total $(0-130)$ & 2.4 & 1.2 & & 502 \\
\hline & & & T1 & $(120-130)$ & 1.4 & 0.0 & & 143 \\
\hline & & & & $(130-140)$ & 4.3 & 0.0 & & 70 \\
\hline & & & & $(140-150)$ & 1.9 & 0.0 & & 108 \\
\hline & & & & total $(0-150)$ & 0.2 & 0.0 & & 3507 \\
\hline
\end{tabular}




\begin{tabular}{|c|c|c|c|c|}
\hline \multirow[t]{9}{*}{ P3 } & $(100-110)$ & 0.2 & 0.0 & 493 \\
\hline & $(110-120)$ & 1.2 & 0.4 & 256 \\
\hline & $(120-130)$ & 2.3 & 0.0 & 12 \\
\hline & $(130-140)$ & 1.8 & 0.0 & 11 \\
\hline & $(140-150)$ & 3.6 & 0.0 & 11 \\
\hline & $(150-160)$ & 2.8 & 0.0 & \\
\hline & $(160-170)$ & 2.5 & 0.0 & \\
\hline & $(170-180)$ & 0.0 & 0.0 & \\
\hline & total $(0-180)$ & 0.6 & 0.2 & 315 \\
\hline
\end{tabular}




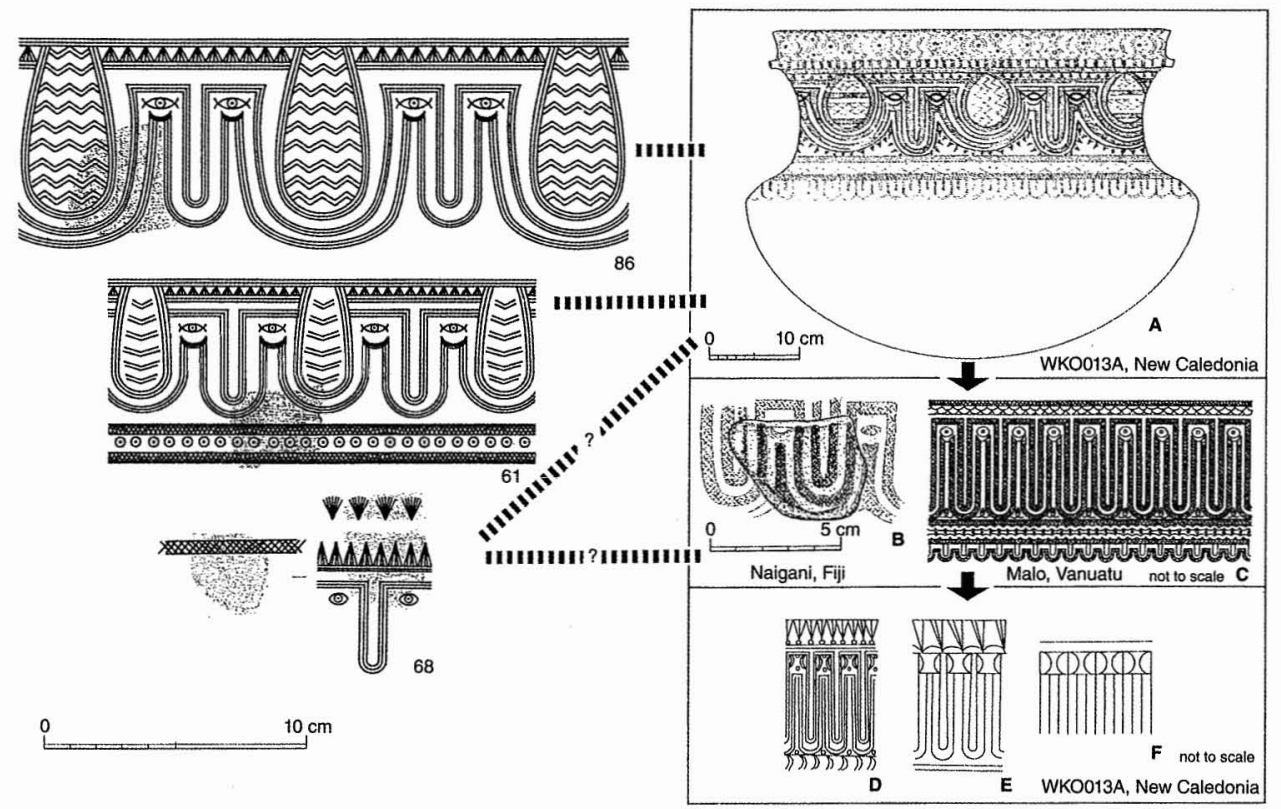

Fig. 7. Reconstructions and associations of selected face designs from the Naitabale Lapita site.
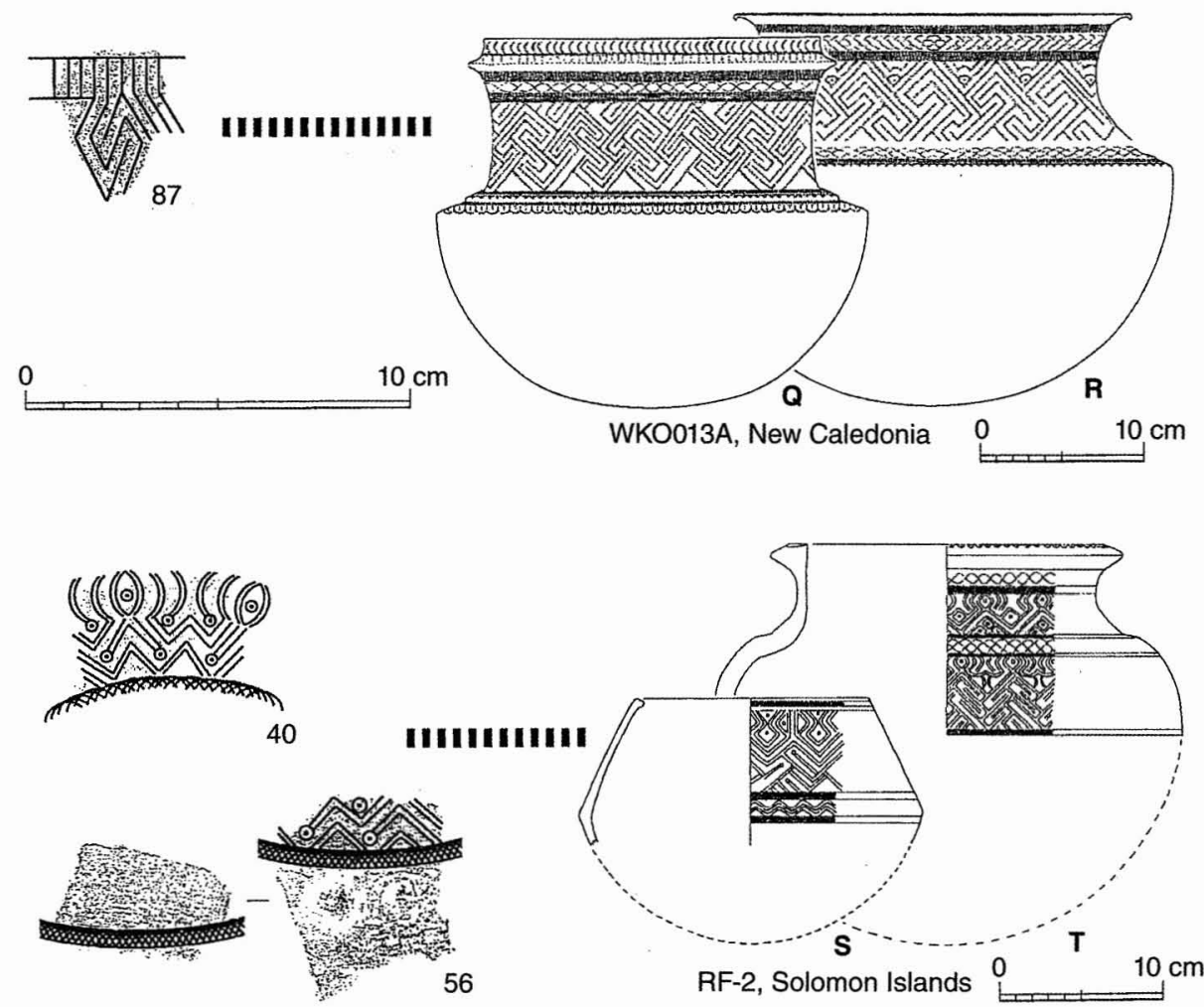

$10 \mathrm{~cm}$

Fig. 8. Reconstructions and associations of selected labyrinth designs from the Naitabale Lapita site. 


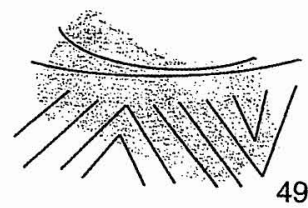

IHIIIIIIII
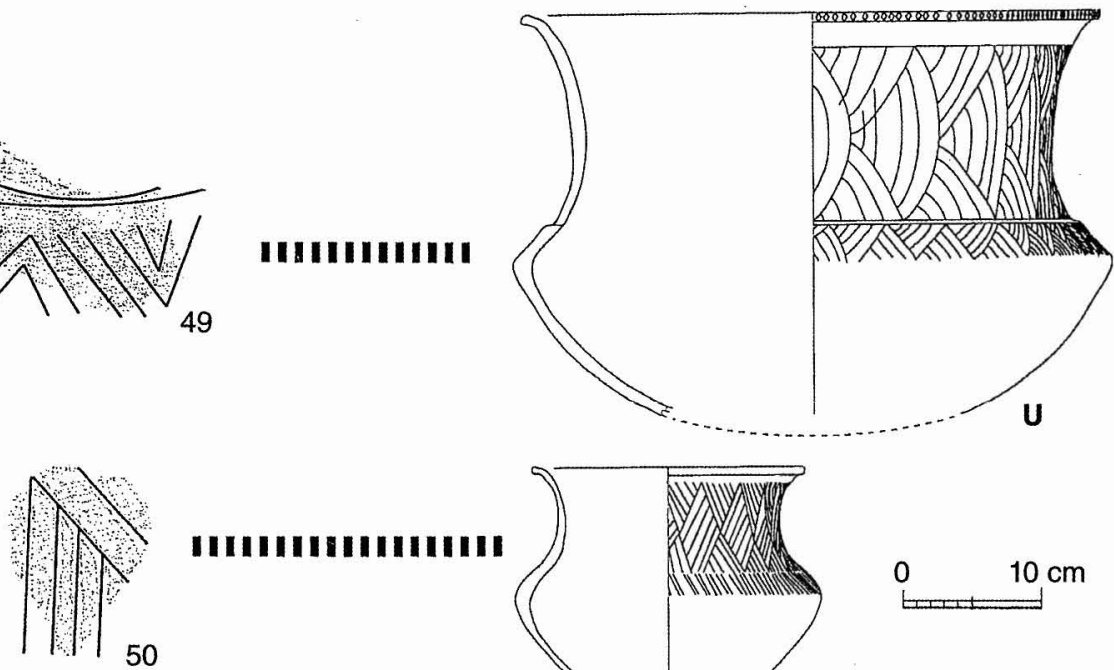

HIHIHIHIHI
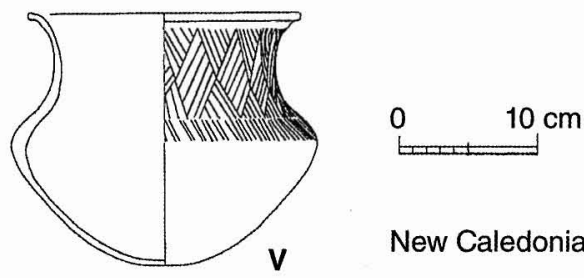

New Caledonia

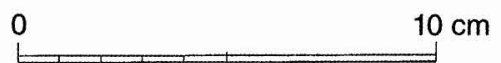

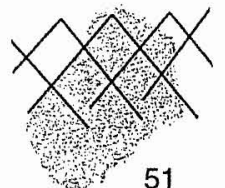

51
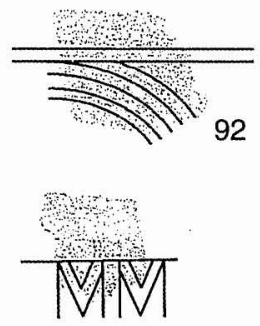

78

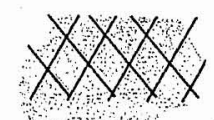

31

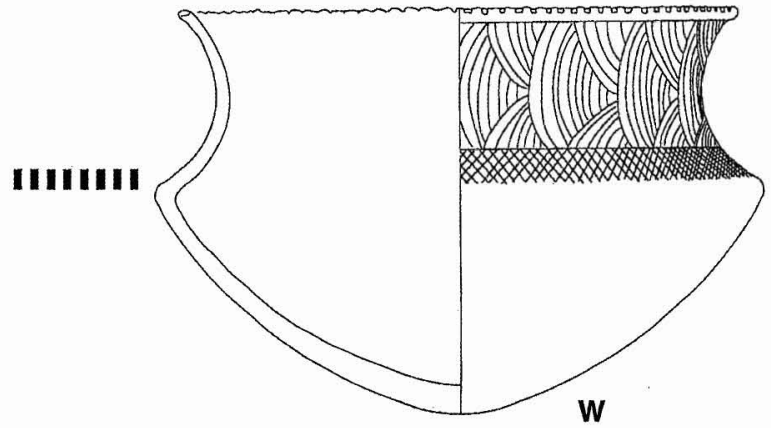

RF-2, Solomon Islands

91
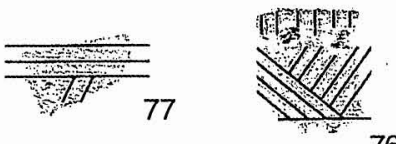

76

Fig. 9. Reconstructions and associations of Lapita incised designs from the Naitabale Lapita site.

\section{Fauna (Excluding Shellfish)}

Some 663 animal bones were collected. This relatively small assemblage was recovered from a number of different layers and excavation pits, with no concentrations that can confidently be assumed to be contemporaneous. Even so, the total assemblage is interesting. The majority (486) were fish bones, of which 156 were identified to taxon-most to family level, but two as elasmobranchs (sharks and rays) and 12 to species (Monotaxis grandoculis, formerly Nemipteridae and now Lethrinidae). The remainder are unidentified teleost (bony) fish. The majority of 
Table 4. Temper Analysis of 32 Standard-Temper Lapita Sherds from Naitabale

\begin{tabular}{|c|c|c|c|c|c|c|}
\hline $\begin{array}{l}\text { SHERD } \\
\text { NUMBER }\end{array}$ & $\begin{array}{c}\% \\
\text { PLAGIOCLASE }\end{array}$ & $\begin{array}{c}\% \\
\text { CLINOPYROXENE }\end{array}$ & $\begin{array}{c}\% \\
\text { HORNBLENDE }\end{array}$ & $\begin{array}{c}\% \text { OPAQUE } \\
\text { IRON } \\
\text { OXIDES }\end{array}$ & $\begin{array}{c}\% \text { VOLCANIC } \\
\text { LITHIC } \\
\text { FRAGMENTS }\end{array}$ & $\begin{array}{c}\text { \% } \mathrm{CPX} / \\
(\% \mathrm{CPX}+ \\
\% \mathrm{HBL})\end{array}$ \\
\hline 3 & 7 & 64 & 9 & 1 & 18 & 0.88 \\
\hline 5 & 8 & 57 & 20 & 12 & 3 & 0.74 \\
\hline 6 & 4 & 70 & 19 & 1 & 6 & 0.79 \\
\hline 17 & 3 & 48 & 29 & 14 & 6 & 0.62 \\
\hline 18 & 3 & 67 & 14 & 7 & 8 & 0.83 \\
\hline 19 & 3 & 48 & 29 & 14 & 6 & 0.62 \\
\hline 21 & 6 & 68 & 15 & 4 & 7 & 0.82 \\
\hline 22 & 8 & 64 & 16 & 7 & 5 & 0.80 \\
\hline 24 & 6 & 69 & 16 & 3 & 6 & 0.81 \\
\hline 34 & 2 & 40 & 47 & 2 & 9 & 0.46 \\
\hline 39 & 14 & 61 & 18 & 1 & 5 & 0.77 \\
\hline 40 & 6 & 74 & 15 & 1 & 4 & 0.83 \\
\hline 42 & 5 & 67 & 14 & 5 & 9 & 0.83 \\
\hline 45 & 5 & 67 & 20 & 3 & 5 & 0.77 \\
\hline 47 & 11 & 64 & 20 & 3 & 2 & 0.76 \\
\hline 48 & 7 & 69 & 13 & 6 & 5 & 0.84 \\
\hline 52 & 2 & 56 & 19 & 21 & 4 & 0.75 \\
\hline 56 & 3 & 77 & 18 & 2 & 1 & 0.81 \\
\hline 57 & 6 & 54 & 7 & 2 & 31 & 0.89 \\
\hline 58 & 6 & 59 & 19 & 5 & 11 & 0.76 \\
\hline 59 & 3 & 78 & 15 & 1 & 3 & 0.84 \\
\hline 60 & 32 & 20 & 5 & 41 & 2 & 0.80 \\
\hline 61 & 6 & 58 & 23 & 6 & 5 & 0.72 \\
\hline 62 & 15 & 62 & 14 & 3 & 6 & 0.82 \\
\hline 63 & 25 & 57 & 14 & 1 & 3 & 0.80 \\
\hline 67 & 3 & 66 & 18 & 13 & 1 & 0.79 \\
\hline 69 & 5 & 59 & 25 & 4 & 7 & 0.70 \\
\hline 70 & 5 & 77 & 16 & 1 & 1 & 0.83 \\
\hline 71 & 7 & 52 & 28 & 3 & 10 & 0.65 \\
\hline 72 & 4 & 48 & 34 & 10 & 3 & 0.59 \\
\hline 73 & 3 & 52 & 35 & 8 & 3 & 0.60 \\
\hline 74 & 2 & 72 & 18 & 5 & 2 & 0.80 \\
\hline Means & 7 & 59 & 19 & 6 & 6 & 0.76 \\
\hline
\end{tabular}

Note: Sherd 34 is interpreted as a hornblende-rich variant of the standard temper and Sherd 60 as an opaque-rich variant of the standard temper.

these were identified by anatomy but could not be assigned to taxa. Of the 177 bones other than fish, 16 were identified as mammal, 9 as bird, and 60 as turtle (Table 5).

In decreasing order of abundance, the most important taxa at Naitabale are Scaridae, Serranidae, Lethrinidae, Balistidae, Labridae, Scombridae, Carangidae, Lutjanidae, Nemipteridae, Elasmobranchii, Diodontidae, Holocentridae, and Acanthuridae. Tetraodontidae are eighteenth in this list. The majority of these fish are inshore species. It is significant that neither Scombridae (fast-swimming pelagic fish such as tunas) nor Carangidae (jacks) are represented at Naitabale. Both are often taken on trolling lures, whereas the other species would be taken either on baited hooks or with nets or spears. 


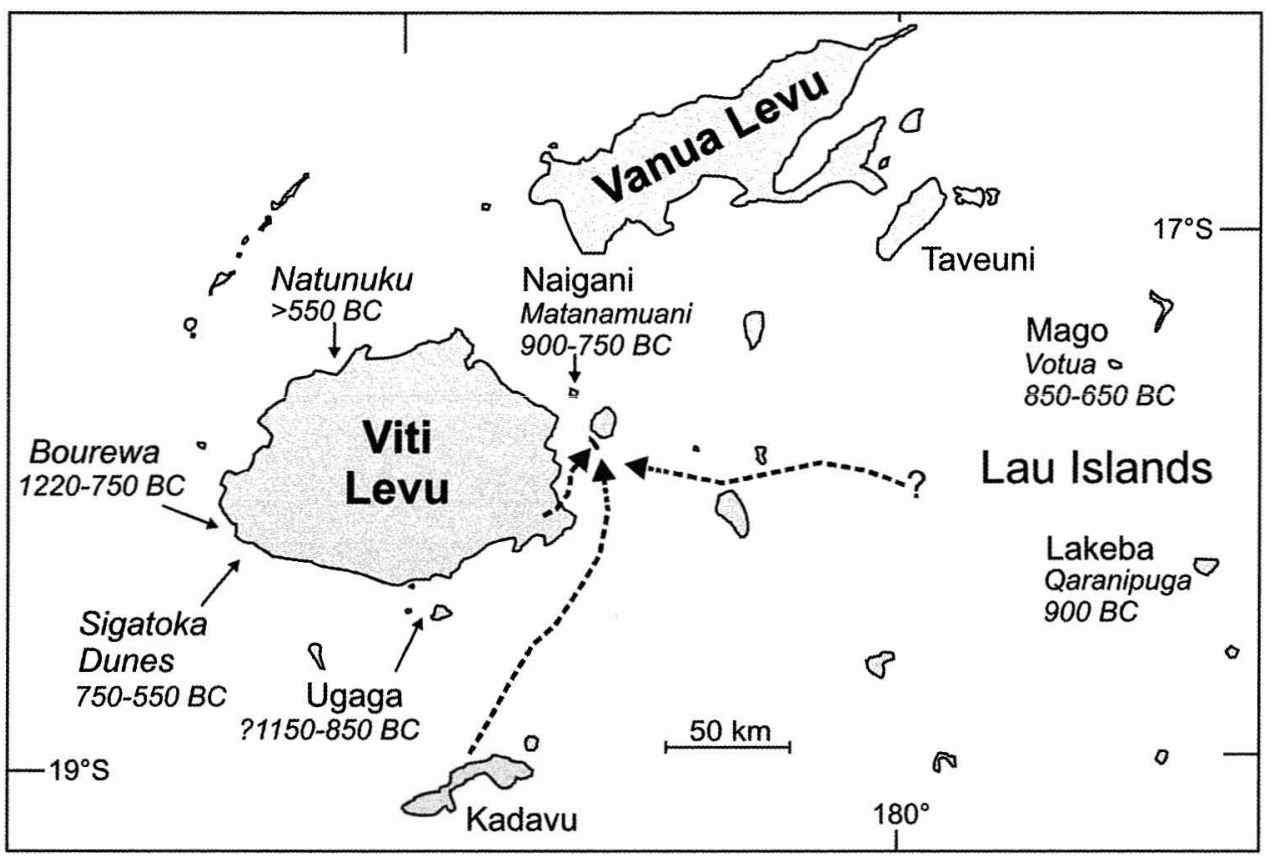

Fig. 10. Sand temper analysis shows that ceramic transfer took place from various parts of Fiji to Moturiki during Lapita times. Although 71 percent of the 45 Lapita sherds examined in thin section were probably manufactured on Moturiki or nearby Ovalau, 11 percent are likely to have come from southeast Viti Levu, where no Lapita site is known, and 11 percent from Kadavu, where no Lapita site is known. A further 7 percent of sherds probably came from Lau, perhaps from the Lapita settlements on Lakeba and Mago.

The relative abundance of the fish families represented in this site is typical of Pacific Island assemblages generally. Leach and Davidson (2000:414) provide an abundance curve for 21,051 identified fish bones (MNI = 13,704) belonging to 48 different taxa (mostly families) from a number of archaeological sites across the Pacific. Although Scombridae and Carangidae are found in small numbers in some Lapita sites (e.g., SE-RF-2 in the Reef Islands of Santa Cruz; Green $1986: 123)$, they do not seem to have been a significant component of the Lapita fish catch. Butler $(1988: 110)$ lists the most important families in fish assemblages from five Lapita sites as Scaridae, Diodontidae, Lethrinidae, Serranidae, Labridae, Lutjanidae, Balistidae, and Acanthuridae. It is clear that the fish assemblage from Naitabale is comparable to other Lapita age fish assemblages and manifests exploitation of the inshore zone.

The presence of pig, dog, chicken, and a relatively large number of turtle bones (Fig. 11) in a site with Lapita sherds is obviously important. Unfortunately, these bones were scattered throughout the site and not all were clearly associated with Lapita pottery. Even so, it is likely that most or all derive from the Lapita occupation.

Turtle bones are common in Lapita sites, and high concentrations are found in colonizing sites (Kirch 1997:202, 225). Although turtle bones dominate the nonfish fauna at Naitabale, they are scattered throughout the deposits and do not 
Table 5. Detalls of Animal Bones Identified from the Naitabale Excavations

\begin{tabular}{lrrrr}
\hline TAXA & MNI & \%MNI & NISP & \%NISP \\
\hline FISH & & & & \\
Acanthuridae & 1 & 0.9 & 1 & 0.6 \\
Balistidae & 7 & 6.2 & 11 & 7.1 \\
Diodontidae & 11 & 9.7 & 15 & 9.6 \\
Elasmobranchii & 2 & 1.8 & 2 & 1.3 \\
Labridae & 8 & 7.1 & 8 & 5.1 \\
Lethrinidae & 20 & 17.7 & 29 & 18.6 \\
Monotaxis grandoculis & 10 & 8.8 & 12 & 7.7 \\
Lutjanidae & 7 & 6.2 & 8 & 5.1 \\
Scaridae & 27 & 23.9 & 39 & 25 \\
Serranidae & 19 & 16.8 & 30 & 19.2 \\
Tetraodontidae & 1 & 0.9 & 1 & 6.4 \\
Unidentified teleost spp. & $?$ & & 330 & 67.9 \\
TOTAL & 113 & & 486 & \\
NONFISH VERTEBRATES & & & & \\
Canis familiaris & 1 & 2.3 & 3 & 3.5 \\
Rattus exulans & 1 & 2.3 & 1 & 9.4 \\
Sus scrofa & 6 & 13.6 & 8 & 1.2 \\
Pteropus sp. & 1 & 2.3 & 1 & 3.5 \\
Sea Mammal? & 3 & 6.8 & 3 & 7.1 \\
Gallus gallus & 6 & 6.8 & 6 & 3.5 \\
other bird bone & 3 & 52.3 & 60 & 70.6 \\
Turtle & 23 & & 85 & \\
TOTAL & 44 & &
\end{tabular}

occur in anything like the density reported by Kirch for the early phase of the TK-4 site on Tikopia (Kirch and Yen 1982).

The tentative identification of sea mammal bones at Naitabale is interesting. Porpoise bones were found at Talepakamalai in the Mussau group, suggesting that these animals were hunted, but Kirch has also drawn attention to their possible spiritual significance for Lapita people (1997:202-203).

Pig, dog, and chicken have all been reported in small numbers from a few Lapita sites, chicken being most numerous and dog rarest (Nagaoka 1988:120). There is a tentative identification of dog from the Lapita site of Naigani. The three fragments identified as dog at Naitabale were found together in association with Lapita sherds near the base of Pit P3. However, the chicken and pig bones and three other possible dog bones (not included in Table 5) were scattered through the deposits, not always in association with dentate-stamped sherds. The Pacific rat, Rattus exulans, accompanied Lapita colonists across the Pacific, presumably as a stowaway, and its bones are common in Lapita sites. Fruit bat (Pteropus sp.) has been reported from several sites in Fiji and elsewhere (Dye 1987: 118; Nagaoka 1988:120).

\section{Shellfish Remains}

Shellfish remains were obtained in large quantities from most pits dug at Naitabale. Close to $218 \mathrm{~kg}$ of identifiable shells, comprising 12,121 NISP and 5583 

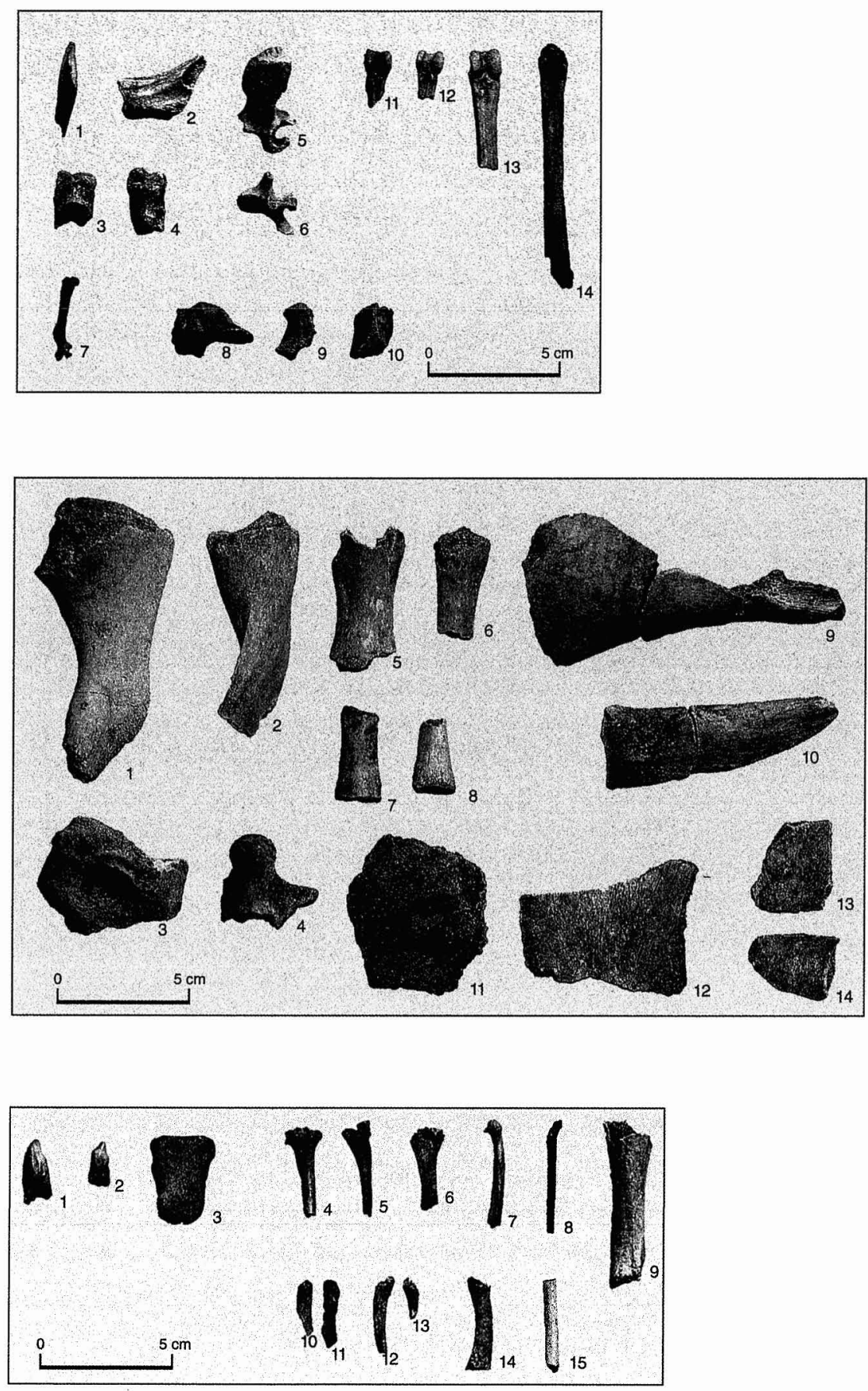

Fig. 11. Animal bones from the Naitabale site: a: 1-6, Sus scrofa; 7, Rattus exulans; 8-10, Canis familiaris; 11-14, Gallus gallus (1, lower second incisor [r]: 2, scapula [r]: 3-4, phalanges: 5-6, vertebra: 7 , femur [1]: $8-10$, vertebra: 11 , tibia [1]: $12-14$, tibia [r]); b: $1-14$, turtle (1, ulna [1]: 2 , radius [l]: 3 , humerus [1]: 4, vertebra: 5 , femur [1]: 6 , femur [r]: $7-8$, phalanges: $9-10$, coracoid [r]: 11 , vertebral shield: $12-14$, shield); c: $1-3$, sea mammal (?); 4-15, unidentified bird bones (1-2, tooth: 3 , tibia [r]). 
Table 6. Details of Shellfish Identified from the Naitabale Excavations

\begin{tabular}{|c|c|c|c|c|c|c|}
\hline SPECIES & MNI & $\begin{array}{l}\text { MNI } \\
(\%)\end{array}$ & NISP & $\begin{array}{l}\text { NISP } \\
(\%)\end{array}$ & $\begin{array}{l}\text { WEIGHT } \\
(\mathrm{g})\end{array}$ & $\begin{array}{l}\text { WEIGHT } \\
(\%)\end{array}$ \\
\hline \multicolumn{7}{|l|}{ Bivalvia } \\
\hline Atactodea striata & 526 & 38.42 & 948 & 27.75 & 980 & 1.60 \\
\hline Anadara antiquata & 187 & 13.66 & 515 & 15.08 & 5761 & 8.42 \\
\hline Gafrarium pectinatum & 186 & 13.59 & 311 & 9.10 & 1,228 & 2.01 \\
\hline Ostrea sp. & 122 & 8.91 & 379 & 11.09 & 12,568 & 20.55 \\
\hline Tellina sp. & 106 & 7.74 & 293 & 8.58 & 1,832 & 3.00 \\
\hline Periglypta puerpera & 96 & 7.01 & 466 & 13.64 & 3,350 & 5.48 \\
\hline Tridacnidae & 75 & 5.48 & 357 & 10.45 & 34,991 & 57.21 \\
\hline Asaphis violascens & 40 & 2.92 & 110 & 3.22 & 334 & 0.55 \\
\hline Fragum $s p$ & 18 & 1.31 & 21 & 0.61 & 66 & 0.11 \\
\hline Pecten sp. & 7 & 0.51 & 9 & 0.26 & 22 & 0.04 \\
\hline Pitar sp. & 4 & 0.29 & 5 & 0.15 & 21 & 0.03 \\
\hline Trachycardium angulatum & 1 & 0.07 & 1 & 0.03 & 2 & $<0.10$ \\
\hline Barbatia velata & 1 & 0.07 & 1 & 0.03 & 3 & $<0.10$ \\
\hline Total & 1,369 & & 3,416 & & 61,158 & \\
\hline \multicolumn{7}{|l|}{ Gastropoda } \\
\hline Strombus spp. & 1,824 & 43.28 & 1,989 & 22.85 & 6,621 & 0.18 \\
\hline Trochidae & 1,016 & 24.11 & 3,581 & 41.14 & 108,868 & 69.68 \\
\hline Turbo sp. & 374 & 8.88 & 1,140 & 13.10 & 15,994 & 10.22 \\
\hline Cypraea spp. & 273 & 6.48 & 546 & 6.27 & 2,571 & 1.64 \\
\hline Nerita spp. & 269 & 6.38 & 305 & 3.50 & 557 & 0.36 \\
\hline Conus spp. & 110 & 2.61 & 430 & 4.94 & 5,511 & 3.52 \\
\hline Polinices sp. & 110 & 2.61 & 128 & 1.47 & 418 & 0.27 \\
\hline Cerithium nodulosum & 75 & 1.78 & 87 & 1.00 & 2,693 & 1.72 \\
\hline Turridae & 63 & 1.50 & 77 & 0.88 & 1,750 & 1.12 \\
\hline Lambis lambis & 61 & 1.45 & 370 & 4.25 & 10,720 & 6.85 \\
\hline Cymatium sp. & 27 & 0.64 & 39 & 0.45 & 270 & 1.75 \\
\hline Terebra sp. & 6 & 0.14 & 7 & 0.08 & 333 & 0.21 \\
\hline Cassis sp. & 2 & 0.05 & 2 & 0.02 & 107 & 0.07 \\
\hline Muricidae & 2 & 0.05 & 2 & 0.02 & 35 & 0.02 \\
\hline Patellidae & 2 & 0.05 & 2 & 0.02 & 11 & 0.01 \\
\hline Total & 4,214 & & 8,705 & & 156,459 & \\
\hline $\begin{array}{l}\text { Total (Bivalvia and } \\
\text { Gastropoda) }\end{array}$ & 5,583 & & 12,121 & & 217,617 & \\
\hline
\end{tabular}

MNI, were analyzed (Table 6). Together with the unidentified specimens, the collection amounted to more than $228 \mathrm{~kg}$ and 14,227 NISP. Gastropods were found to make up the bulk of the shellfish, accounting for 75 percent MNI, 72 percent NISP, and 72 percent of the total weight. Strombus spp. and the Trochidae family (Trochus niloticus and Tectus pyramis) make up 43 percent and 24 percent of the gastropod MNI, respectively. Among bivalves, the small surf clam (Atactodea striata) accounts for 38 percent of MNI. Other relatively abundant taxa include Anadara antiquata and Gafrarium pectinatum, each representing 14 percent of the bivalve MNI. All other species (bivalves and gastropods) are represented by less than 10 percent of MNI.

Data from other Lapita sites in Fiji have led to the suggestion that local availability of shellfish resources may have been more important than selection of familiar kinds of shells (Nagaoka 1988). It is possible, however, that shellfish gath- 
ering may actually reflect a mixture of availability and preference (Clark et al. 2001; Thomas et al. 2004). Variable selection within a broad spectrum of shellfish resources is consistent with an approach to subsistence that weighs the variable costs and benefits that human foragers face while collecting prey, as shown ethnographically (Bird and Bird 1997; Thomas 2002) and through the examination of archaeological data (Anderson 1981; Raab 1992).

Gastropods such as Strombus spp. tend to aggregate, a trait common to most members of the genus (Catterall and Poiner 1983). Thus, when a shellfish gatherer encounters one specimen, this increases the probability of encountering others. From a cost-benefit perspective, this can influence the profitability of a prey type (Botkin 1980; Madsen and Schmitt 1998).

Trochus niloticus and Tectus pyramis are found on shallow-water reef flats, where they feed on algae, although larger individuals $(30-90 \mathrm{~mm}$ in length) of T. niloticus may graze to depths of $20 \mathrm{~m}$ (Abbott and Dance 2000). As adults, Trochidae are sedentary animals, and their movements are limited to distances of no more than a few tens of meters in their lifetimes (Nash 1988). This factor, together with the potential meat packet offered by the larger specimens, make $T$. niloticus a particularly attractive resource. As with most archaeogastropods, $T$. niloticus has limited dispersal of larvae, making it difficult to replenish heavily exploited adult stock (Wells 1989). In the Reef-Santa Cruz group of the southeastern Solomon Islands, Swadling (1986) documented significant size reduction for this species in the upper Lapita layers compared to earlier deposits.

Although yielding an average of less than $1 \mathrm{~g}$ of edible meat, the small bivalve Atactodea striata often occurs in large densities along beaches and is easily accessible by digging in less than $5 \mathrm{~cm}$ of sand, making it an attractive resource. Anadara antiquata and related species were and continue to be popular throughout the $\mathrm{Pa}$ cific (Amesbury 1999; Spennemann 1987; Tebano and Paulay 2001). This cockle is large, easily accessible, and requires simple processing. While smaller than $A$. antiquata and buried up to $15 \mathrm{~cm}$ deep in the sand, Gafrarium may be locally abundant. On Tarawa, Kiribati, it remains an important secondary catch among modern shellfish gatherers (Paulay 2001).

Measurements of length and diameter for A. antiquata, T. niloticus, and Tectus pyramis did not reveal any statistically significant change in species size that might be attributable to human predation and/or environmental factors (two-tailed probability t-test separate variance estimate $p>.05$ ). One exception is for Trochidae excavated from Pit T1 between $80-130 \mathrm{~cm}$, with a mean diameter of $82.30 \mathrm{~mm}$ (layer dated to $2720-2350 \mathrm{cal}$. years B.P.) and between $60-80 \mathrm{~cm}$ with a mean diameter of $64.63 \mathrm{~mm}$ (layer dated to $500-300 \mathrm{cal}$. years B.P.), although the probability is only weakly supported $(.01<p<.05)$.

The evidence for total shell weight by spit and pit location suggests that human impact may have led to a decline in shellfish resources over time. Figure 12a illustrates shell weights for each $10 \mathrm{~cm}$ spit. It can be concluded that harvesting was generally more intense during the site's early occupation and declined during its later human history. This pattern of intense harvesting of wild resources, including shellfish, has been noted in other contexts and is characteristic of subsistence strategies by colonizing groups in pristine island ecosystems (Best 1984; Kirch and Yen 1982). Figure $12 \mathrm{~b}$ shows total shell weight density per cubic meter for each pit. Of particular interest is the low density of shells from Pit P2 $\left(153 \mathrm{~g} / \mathrm{m}^{3}\right)$. This 

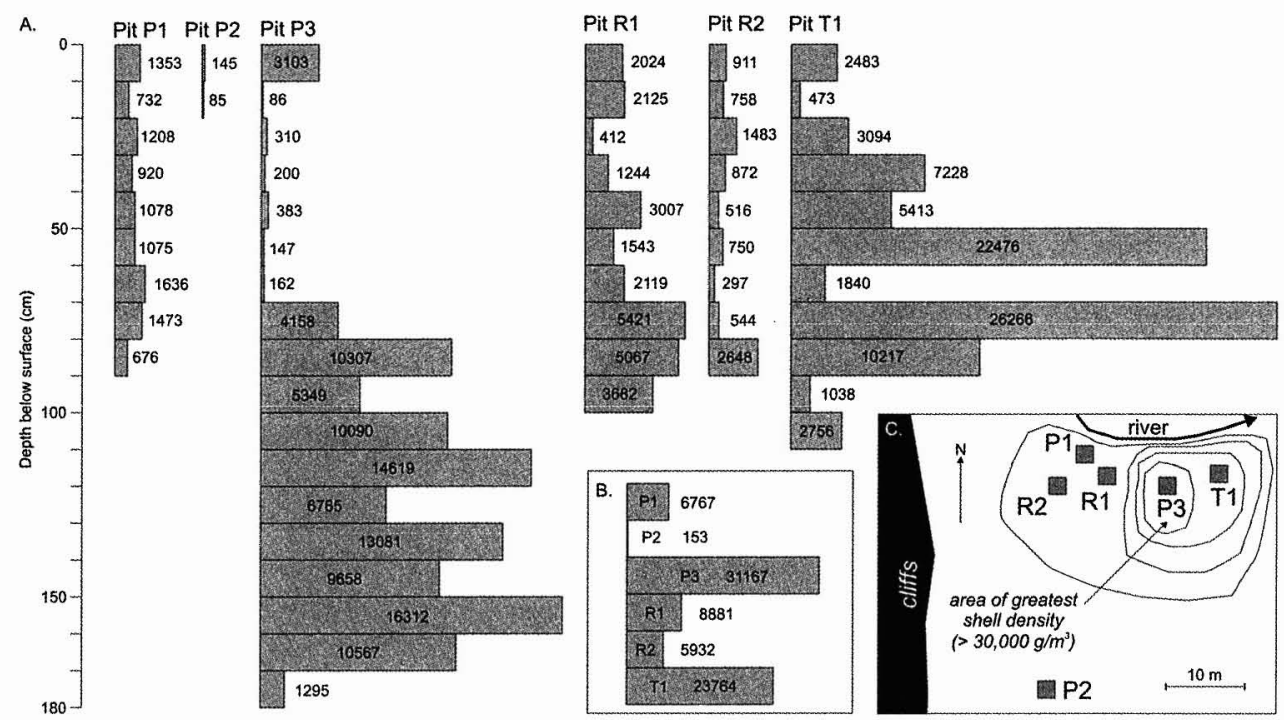

Fig. 12. a: Main diagram: Weights of shells (g) from each spit in six pits at Naitabale. Note how in most pits there is a concentration of shells in the lower spits and fewer in the upper spits, indicating that Naitabale was occupied intensively early in the history of this area but much less so later on, when the shoreline had prograded seaward. b: Total shell weight density by pit $\left(\mathrm{g} / \mathrm{m}^{3}\right)$. Note that the horizontal scale used is different from that in a. c: Map of the central part of Naitabale (from Fig. 3a) showing contours of shell density. The greatest shell density is in Pit P3. The $20,000 \mathrm{~g} / \mathrm{m}^{3}$ contour encloses Pits P3 and T1, from which area the concentration of shells falls markedly. Other contours are shown at 10,000 and $5000 \mathrm{~g} / \mathrm{m}^{3}$.

pit is located closest to the modern shoreline (Fig. 12c). Although no radiocarbon dates are available for this pit, it is assumed to mark the later period of Lapita occupation of the site given its location on the seaward side of the Lapita beach ridge, in the lee of which Lapita settlement was concentrated (see Fig. 3b). By contrast, the other pits, located farther inland, yielded much higher shell densities.

\section{Human Skeletal Analysis}

The human skeleton recovered from Naitabale (see Fig. 5) comprised a nearly complete skull and fragmentary postcranial bones, brown to light brown in color and encrusted with beach sand. The skeleton was named "Mana" by its discoverer, Solomon Islander Chris Suri; the name means "the truth" in the Lau dialect of Malaita. The bones were not fossilized, their light weight implying that much of their organic matrix had been lost prior to disinterment. The skull was extraordinarily well preserved (see below); a total of 24 teeth were present, with only one missing postmortem. The infracranial skeleton was rather poorly preserved; the foot and hand bones were best preserved (Katayama et al. 2003).

Judging from the wide greater sciatic notch and the raised auricular surface, the skeleton is that of a female, a conclusion consistent with other observations (relatively small mastoid processes, weakly raised superciliary arches, sharp supraorbital margins, clearly recognizable frontal bosses, gracile zygomatic bones). At death the individual was 40-60 years old, an estimate based on the degree of remodeling of the auricular surface (Lovejoy et al. 1985) and the state of ectocranial suture 
closure (Meindl and Lovejoy 1985) and confirmed by the extensive tooth wear and loss and the presence of degenerative joint changes.

Analysis of the postcranial skeleton was hampered by its incomplete nature, although maximum lengths of the nearly complete left tibia and humerus were possible. Stature was estimated using regression formulae for Polynesians (Houghton et al. 1975) and the White and Mongoloid ethnic groups (Trotter 1970). The individual appears to have been $161-164 \mathrm{~cm}$ tall, a slightly greater value than that for living Pacific Island females $(157.2-161.8 \mathrm{~cm}$; Houghton 1996).

A weak scar at the preauricular sulcus on the right pelvis suggests that the individual had given birth to at least one child. Deltoid tuberosity is better developed on the right humerus, suggesting that the individual was right-handed. The overall health status of the individual had been good, although examples of bone fracture and degenerative changes were observed on the humeri. Her body would have been tall, muscular, and tough - an excellent constitution for an elderly lady. Like many of the other Lapita-era skeletons known, morphological observations of this one suggest adaptations resulting from heavy mastication and strenuous physical activity involving the neck, arms, and feet.

When the skeleton was first examined, the skull was broken into many pieces, but it proved possible to substantially restore it around the well-preserved cranium and mandible (Fig. 13a). The cranium is the most complete Lapitaassociated cranium ever described, being substantially more intact than those found on Waya Island in Fiji (Pietrusewsky et al. 1997a, 1997b) and at Koné, New Caledonia (Pietrusewsky et al. 1998). The cranium is relatively short, although of normal proportions. The vault shape (cranial index) of 80.1 allows it to be classified as brachycranic. The mandible lacks antegonial notches, but it is not a proper rocker jaw, being in a semirocker state. The cranial vault bones and mandible appear thick and massive. In posterior view, the neurocranium appears pentagonal in shape. In lateral view, the face is very flat owing to the weak prominence of the glabella portion, the weak depression of the nasion, and the weak protrusion of the nasal bone.

The exposed tooth roots are brown in color, perhaps due to something eaten or chewed. Similar discoloration of teeth in skeletons from the Sigatoka Sand Dunes (Fiji) may have resulted from chewing roots of Piper methysticum for the preparation of kava (Visser 1994). The attrition pattern of the mandibular anterior teeth suggests edge-to-edge biting. Dental heath of this individual was very poor, with numerous caries observed.

Uniquely among Lapita-era skeletons in the Pacific, the skull of Mana was exceptionally well preserved, allowing a model of the head and face to be made (Fig. 13b) using techniques described in Prag and Neave (1997). The head is of great interest in that it is the first time the face of a Lapita person has been accurately rendered, yet it adds very little objective scientific detail to the above analysis.

Diet - Stable-isotope analyses were carried out on three samples of human bone collagen from the Naitabale skeleton (Table 7).

The ${ }^{13} \mathrm{C}$ values for the Naitabale skeleton and those from prehistoric human bone elsewhere in the tropical Pacific are shown graphically in Figure 14a. 
A.
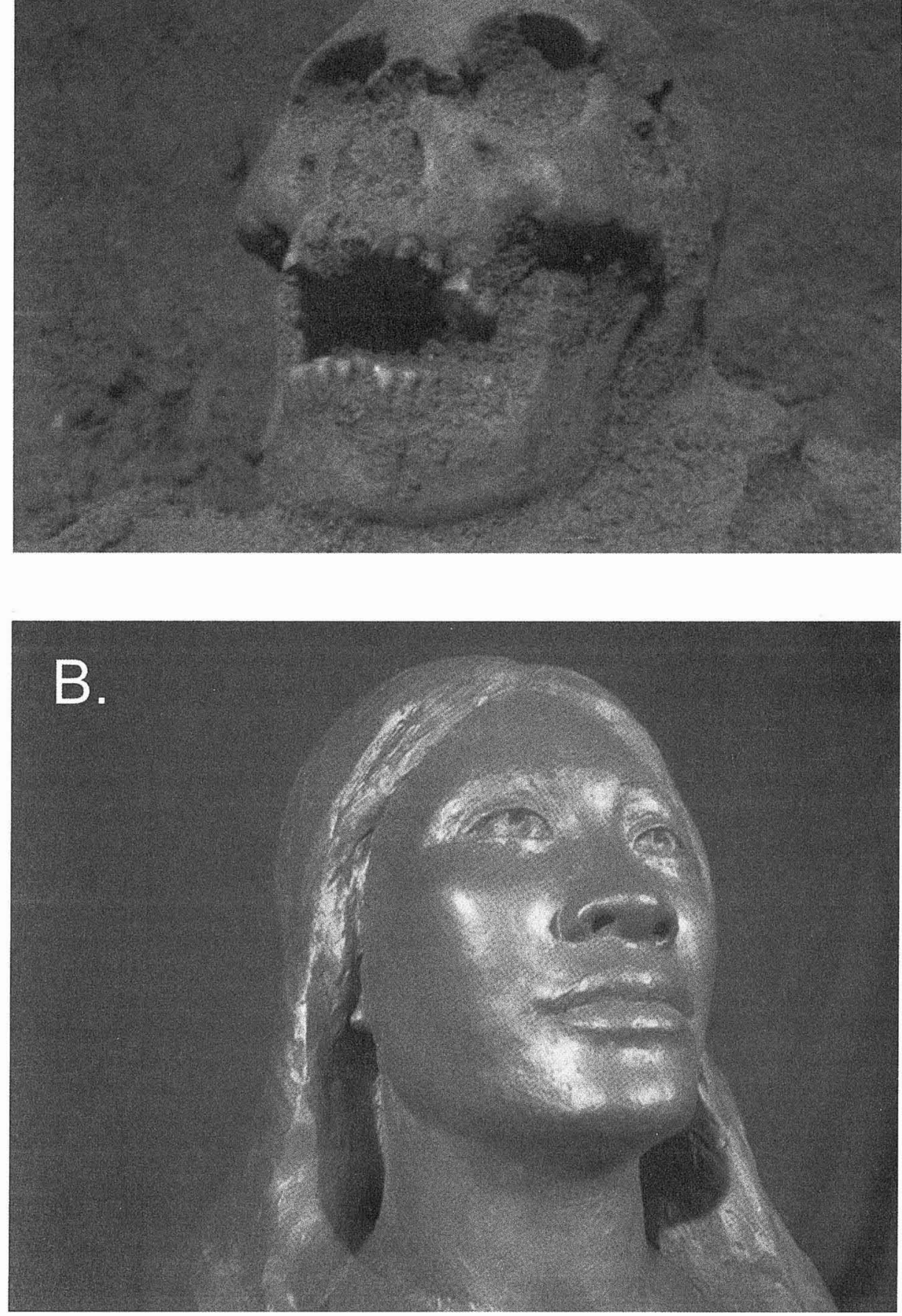

Fig. 13. a: The skull of the Lapita-era female (Mana) photographed prior to disinterment from Pit T1 at Naitabale. b: The reconstructed head of the Lapita-era female whose skeleton was disinterred from the Naitabale site. 
Table 7. Stable-Isotope Analyses of Human Bone Collagen from Naitabale

\begin{tabular}{llcccrr}
\hline SAMPLE & \multicolumn{1}{c}{ BONE } & \% CARBON & \% NITROGEN & $\delta^{13} \mathrm{C} \%$ & $\delta^{\mathrm{I5}}$ N\% & $\mathrm{C} / \mathrm{N}$ \\
\hline MANA-4 & long bone & 43.10 & 15.287 & -15.86 & 9.36 & 3.29 \\
MANA-7 & first right rib & 42.41 & 14.355 & -16.00 & 9.43 & 3.45 \\
MANA-11 & femur & 42.77 & 15.308 & -15.82 & 9.80 & 3.26 \\
\hline
\end{tabular}

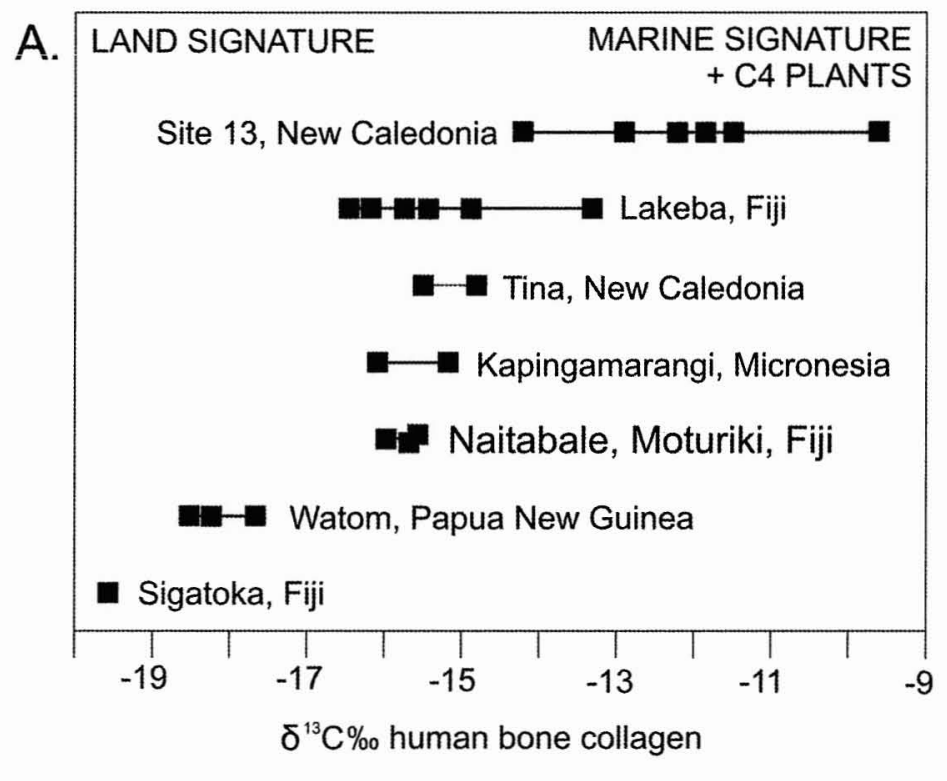

B.

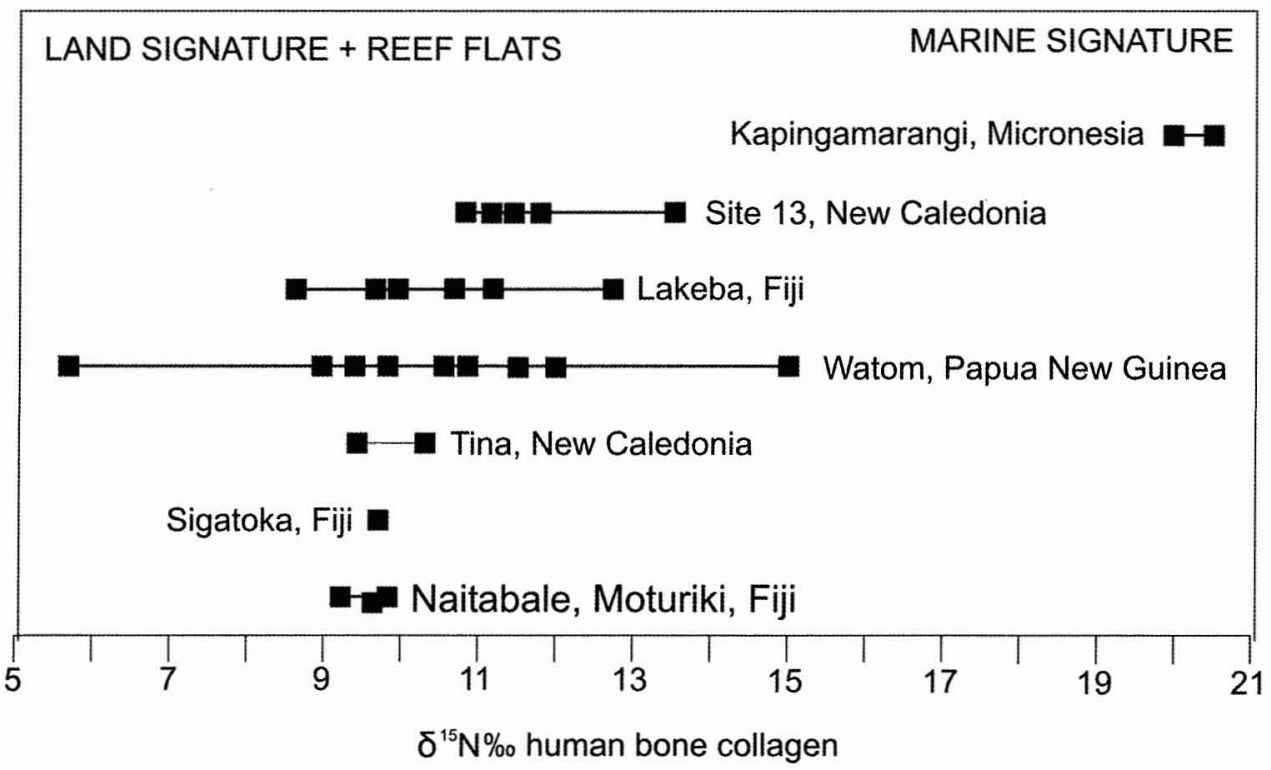

Fig. 14. Stable-isotope data from analyses of human bone collagen from Naitabale plotted against comparable data from tropical Pacific Islands (data from Davidson and Leach 2001). 
Table 8. Radiocarbon Dates from the Naitabale Excavations, Moturiki Island

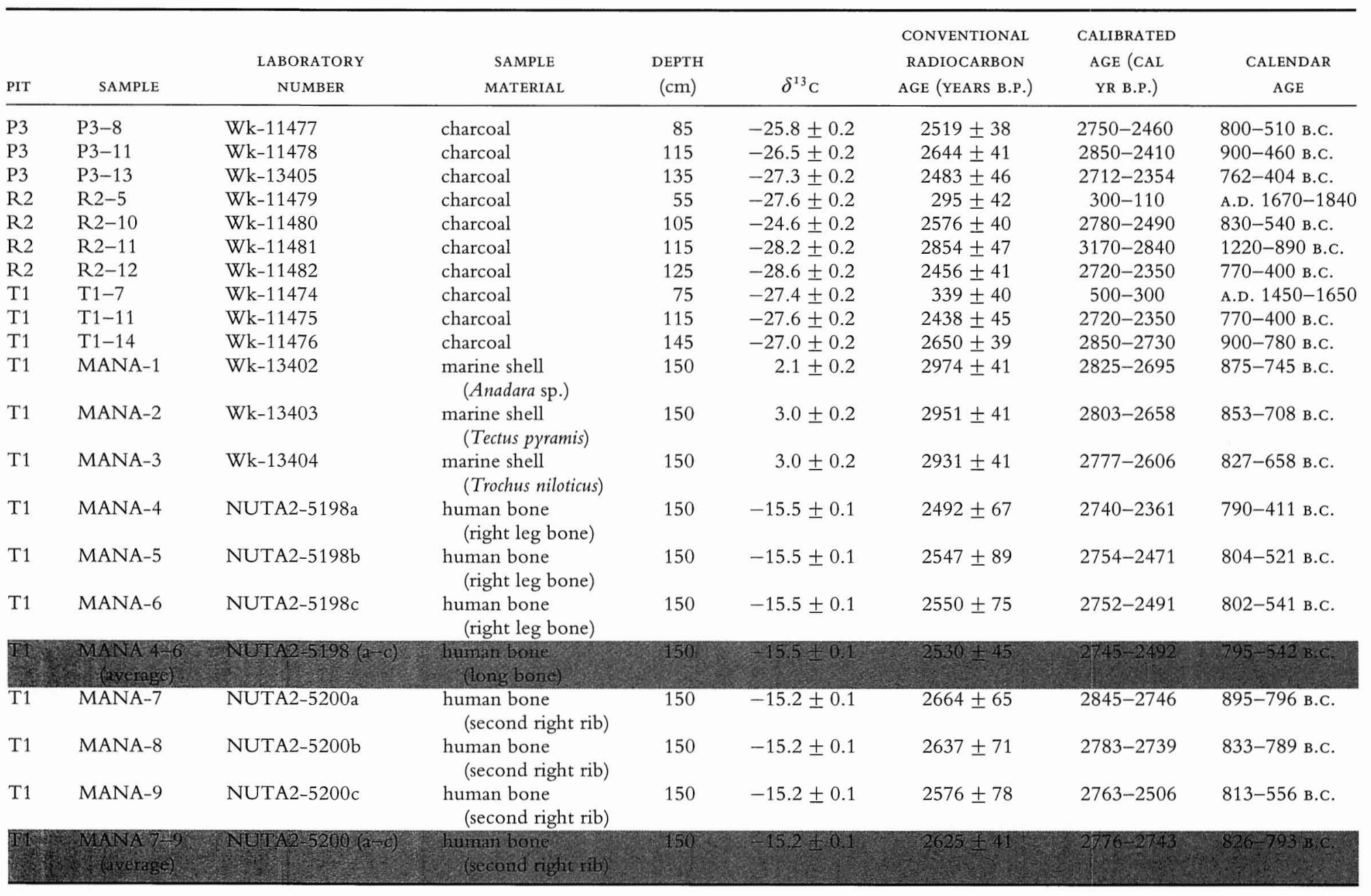

Note: Ages calibrated using OxCal (version 3.5) and, for marine shell, CALIB Marine93.14c curve; 2 sigma range given. Wk dates from the University of Waikato Radiocarbon Dating Laboratory, NUTA dates from Nagoya University Radiocarbon Dating Laboratory. Note that the shaded rows do not represent separate dates but the averages of the three duplicate dates above. 
The ${ }^{13} \mathrm{C}$ signatures are likely to indicate the consumption of shellfish and smaller (reef-lagoon) fish species, although they may indicate consumption of C4 plants such as sugarcane (Saccharum officinarum) or duruka (Saccharum edule), which was almost certainly a pre-European introduction to Fiji (Parham 1972). While it appears from Figure 14a that the Lapita people of Naitabale did not have as large a terrestrial component in their diet as those at Watom (Leach et al. 2000), for example, terrestrial plants are likely to have played an important role at Naitabale, perhaps even contributing more than reef-flat species.

The ${ }^{15} \mathrm{~N}$ signatures of animals living in the inshore reef-flat group overlap with terrestrial organisms rather than marine ones, adding difficulty in ascertaining the diet of this individual. It is likely that people at most sites in Figure $14 \mathrm{~b}$ had diets that were dominated by inshore reef-flat foods-and that certainly seems to be the case at Naitabale.

In general, the results suggest that this individual had a mixed marine-terrestrial diet, dominated by shellfish (and crustacea?) but containing significant amounts of fish and slightly lesser amounts of terrestrial animals. This is very similar to the results of nonhuman bone analysis (see above and Table 5). Yet it does make the issue of how to correctly calibrate the conventional radiocarbon ages from the human bone somewhat difficult to resolve (see below).

Diet reconstruction using stable isotopes is a new technique, and some of the associated problems and possibilities are still being explored (Leach et al. 2003). In particular, it is clear that there is considerable variation within communities, so that samples from one individual are unlikely to be representative.

\section{Radiocarbon Dating}

Radiocarbon determinations were obtained for three categories of material excavated at Naitabale: charcoal, edible shellfish remains, and human bone. Data are listed in Table 8 and depicted graphically in Figure 15.

The charcoals dated were found as lumps typically $25 \mathrm{~mm}^{3}$ in situ within the pits and are assumed to have been produced following burning of wood by humans around the same time as the deposit was laid down. Although there is broad consistency of charcoal ages within pits, there are minor anomalies (see Figure $4 \mathrm{a}$, for example) attributable to sediment reworking or to the burning of old (rather than recently alive) wood. The latter might explain why the earliest radiocarbon age from Naitabale (calibrated to $1220-890$ B.C.) is significantly earlier than the rest of the Lapita-era ages (see Fig. 15).

The edible shells dated all appeared to have been deliberately associated with the human burial: one beneath the head (for support?), two between the knees (see Fig. 5). The radiocarbon ages from shell show little difference from most charcoal dates, an observation that suggests the (main?) Lapita occupation at Naitabale may have been only a few hundred years in duration.

Small pieces of human bone from the burial were also dated. Three dates were obtained for each of two samples, one from the leg bone, the other from a rib. The results were not marine-corrected although it is likely that, owing to what we know of this individual's diet (see above), they are probably slightly too young. The results from each sample of the six samples overlap only between 2740-2739 cal yr B.P. (790-789 в.C.). Dates from the skeleton are similar to those from other indications of occupation age at Naitabale (Figure 15). 


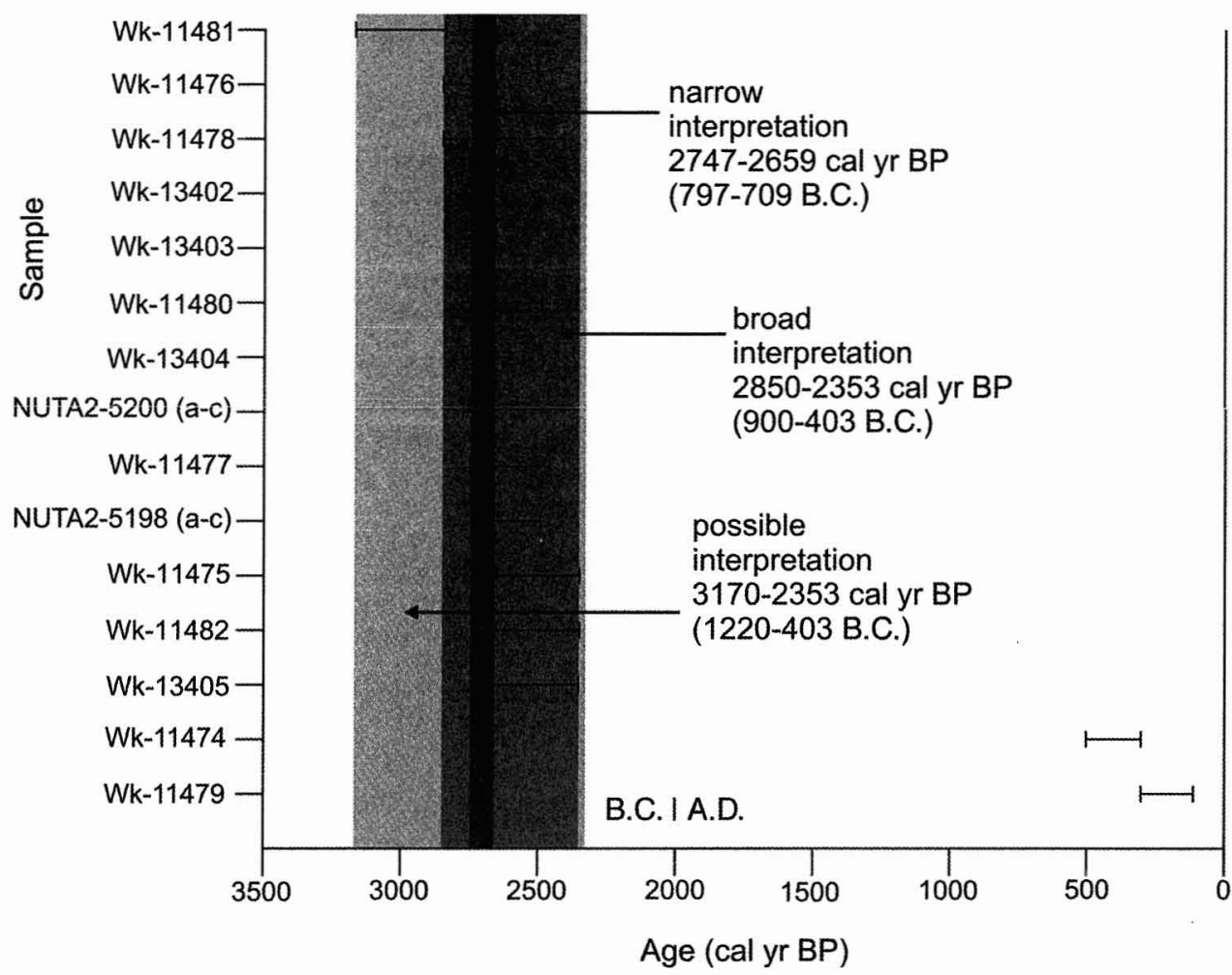

Fig. 15. Calibrated radiocarbon ages for indicators of Lapita-era occupation at the Naitabale site (listed in Table 8).

Three interpretations of the time of occupation of the Naitabale site are shown in Figure 15.

The "narrow interpretation" - the band that touches all age ranges apart from that assumed to come from old wood (Wk-11481)-shows occupation of the site 2747-2659 cal. years B.P. (797-709 B.C.). This is regarded as the most conservative interpretation of the dates.

The "broad interpretation"- the band that encompasses the age ranges of all samples except Wk-11481-shows occupation 2850-2353 cal. years B.P. (900403 B.C.). The earlier end of this age range is likely to be close to actual site establishment time, putting it in the same era as the Matanamuani site on nearby Naigani Island (established perhaps 2900 cal. years B.P.; Best 2002). The younger end of this range is likely to be too young, given that the end of the Lapita history of Fiji was perhaps 2700 cal. years B.P. (Anderson and Clark 1999).

The possible interpretation - the band that encompasses all age ranges-shows that occupation could have begun as much as 3170 cal. years B.P. (1220 B.C.). As discussed above, this interpretation rests on a single charcoal sample that, owing to its apparently anomalous age, may not be an accurate indicator of the site's human occupation. Conversely, the time of Lapita arrival in Fiji may have been slightly earlier than 3000 cal. years B.P. (2950 B.C.), given the suite of early ages from the Bourewa site in southwest Viti Levu (Nunn et al. 2004a) and the ages 
for the same event in Tonga (Burley et al. 2001; Spriggs 2002), so this interpretation remains a possibility.

\section{CONCLUSIONS}

The Lapita settlement at Naitabale, in the south of Moturiki Island, central Fiji, was founded in a back-beach location near what was then the mouth of the Mataloaloa River close to one of the broadest fringing reefs in the area. Judging by the decorative associations of the dentate-stamped potsherds, 29 percent of which are exotic to the island, the site was likely established early in the Lapita history of Fiji, a view borne out to some extent by radiocarbon dates. The inhabitants of Lapita-era Naitabale consumed mostly marine foods-largely shellfish, turtle, and inshore-dwelling fish species-but with some terrestrial commensals, including chicken. A well-preserved human skeleton was of a female. The Lapita occupation of Naitabale is likely to have been about 2950-2600 cal. years B.P. (1000-650 в.C.).

Many of the conclusions stated above are tentative, based on plausible interpretations of the available results. Were more work to be carried out at this site, some of these conclusions might change. Additional research into the Lapita-era occupation of central Fiji might, on the basis of what was found at Moturiki, focus on identifying the Lapita sites that are inferred to exist (from sherd temper analyses) in southeast Viti Levu and Kadavu and trying to understand the interactions between these and others in the area, including Naitabale.

\section{ACKNOWLEDGMENTS}

This research was carried out with the full support of the people of Moturiki Island. We wish especially to thank the ratu mai Moturiki, Ratu Alifereti Draunidalo; Tevita Bukasoqo, the chief of Uluibau; and Mesake Jale Raratabu (naitaka), the chief of Nasauvuki. For field support, we are grateful to the resourceful and hardworking team of university students that was in the field for a wet three weeks: Francis Areki, Taati Eria, Michael Foon, James Leo, Alifereti Nasila, Tamara Osborne, Tufoua Panapa, Tui Raicebe, Lisa-Marie Shillito, Preetika Singh, Chris Suri, Esther Tegu, Nunia Thomas, and Samuela Tukidia. For photography and video shooting, we thank Christopher Robbins and Sangeeta Singh. The model of the head of Mana was made at Kyoto Kagaku Inc. in Japan. We thank Dr. Hirotaka Oda (Nagoya University) for radiocarbon analysis of the human skeleton, Professor Masao Minagawa (Hokkaido University) for stable-isotope analysis, Dr. Melanie Allen and Jacqueline Craig (University of Auckland) and Professor Michael Richards (Bradford University) for helping interpret this, Johnson Seeto for assistance with shell identification, and Aana Bureteiti and Vicky Claude for help with shell analysis. This research was funded largely by the University of the South $\mathrm{Pa}-$ cific through research grants 6585 and 6546.

\section{REFERENCES}

Aвbott, R. T., And S. P. DAnCe

2000 Compendium of seashells. El Cajon, CA: Odyssey.

Amesbury, J. R.

1999 Changes in species composition of archaeological marine shell assemblages in Guam. Micronesica $31: 347-366$. 
Anderson, A.

1981 A model of prehistoric collecting on the rocky shore. Journal of Archaeological Science 8:109-120.

2003 Initial human dispersal in Remote Oceania: Pattern and explanation, in Pacific Archaeology: Assessments and Prospects (Proceedings of the International Conference for the Fiftieth Anniversary of the First Lapita Excavation, Kone-Nouméa 2002): 71-84, ed. C. Sand. Nouméa: Services des Musées et du Patrimoine.

Anderson, A., and G. Clark

1999 The age of Lapita settlement in Fiji. Archaeology in Oceania 34:31-39.

Anson, D.

1983 The Lapita Pottery of the Bismarck Archipelago and its Affinities. Ph.D. diss. University of Sydney, Australia.

BEDFORD, S.

2003 The timing and nature of Lapita colonisation in Vanuatu: The haze begins to clear, in $\mathrm{Pa}$ cific Archaeology: Assessments and Prospects (Proceedings of the International Conference for the Fifteith Anniversary of the First Lapita Excavation, Kone-Nouméa 2002): 147-158, ed. C. Sand. Nouméa: Services des Musées et du Patrimoine.

BeSt, S.

1981 Excavations at Site VL 21/5 Naigani Island, Fiji: A Preliminary Report. Auckland: Department of Anthropology, University of Auckland.

1984 Lakeba: The Prehistory of a Fijian Island. Ph.D. diss. University of Auckland, New Zealand.

2002 Lapita: A View from the East. New Zealand Archaeological Association Monograph 24. Auckland: NZAA.

BIRD, D. W., AND R. B. BIRD

1997 Contemporary shellfish gathering strategies among the Meriam of the Torres Strait Islands, Australia: Testing predictions of a central place foraging model. Journal of Archaeological Science $24: 39-63$.

BоткIN, S.

1980 Effects of human exploitation on shellfish populations at Malibu Creek, California, in Modeling Change in Prehistoric Subsistence Economies: 121-139, ed. T. K. Earle and A. L. Christenson. New York: Academic Press.

Burley, D. V., AND J. T. Clark

2003 The archaeology of Fiji/West Polynesia in the post-Lapita era, in Pacific Archaeology: Assessments and Prospects (Proceedings of the International Conference for the Fiftieth Anniversary of the First Lapita Excavation, Kone-Nouméa 2002): 235-254, ed. C. Sand. Nouméa: Services des Musées et du Patrimoine.

Burley, D. V., W. R. Dickinson, A. Barton, and R. Shutler JR.

2001 Lapita on the periphery: New data on old problems in the Kingdom of Tonga. Archaeology in Oceania 36:89-104.

Butler, V. L.

1988 Lapita fishing strategies: The faunal evidence, in Archaeology of the Lapita Cultural Complex: A Critical Review: 99-115, ed. P. V. Kirch and T. L. Hunt. Seattle: Thomas Burke Memorial Washington State Museum Research Report 5.

Catterall, C. P., and I. R. Poiner

1983 Age- and sex-dependent patterns of aggregation in the tropical gastropod Strombus luhuanus. Marine Biology 77 :171-182.

Clark, G., and A. Anderson

2001 The pattern of Lapita settlement in Fiji. Archaeology in Oceania 36:77-88.

Clark, G., A. Anderson, and S. Matararaba

2001 The Lapita site at Votua, northern Lau Islands, Fiji. Archaeology in Oceania 36:134-145.

Cochrane, E.

2004 Archaeological investigations on Waya Island: The 2001 University of Hawai'i archaeological field school. Domodomo 17:7-13.

Crosby, A.

1988 Beqa: Archaeology, Structure and History in Fiji. Unpublished M.A. thesis. University of Auckland. 
Davidson, J., E. Hinds, S. Holdaway, and F. Leach

1990 The Lapita site of Natunuku, Fiji. New Zealand Journal of Archaeology 12:121-155.

DAvidson, J., AND F. LEACH

2001 The strandlooper concept and economic naivety, in The Archaeology of Lapita Dispersal in Oceania: 115-123, ed. G. R. Clark, A. J. Anderson, and T. Vunidilo. Canberra: Australian National University (Pandanus Books).

Dickinson, W. R.

2001 Petrography and geologic provenance of sand tempers in prehistoric potsherds from Fiji and Vanuatu, South Pacific. Geoarchaeology 16:275-322.

Dickinson, W. R., R. Shutler Jr., R. Shortland, D. V. Burley, and T. S. Dye

1996 Significance of sand tempers in indigenous Lapita and Lapitoid Polynesian Plainware and imported Fijian pottery of Ha'apai (Tonga) for the question of Lapita tradeware. Archaeology in Oceania 31:87-98.

Donovan, L. J.

1973 A Study of the Decorative System of the Lapita Potters in Reefs and Santa Cruz Islands. M.A. Research Essay, University of Auckland, New Zealand.

DYE, T. S.

1987 Social and Cultural Change in the Prehistory of the Ancestral Polynesian Homeland. Ph.D. diss. Yale University, New Haven, CT.

FrimigacCI, D.

1975 La Préhistoire Neo-Calédonien. Thèse de 3e Cycle. Université Paris I.

Green, R. C.

1979 Lapita, in The Prehistory of Polynesia: 27-60, ed. J. Jennings. Cambridge: Harvard University Press.

1986 Lapita fishing: The evidence of Site SE-RF-2 from the main Reef Islands, Santa Cruz Group, Solomons, in Traditional Fishing in the Pacific (Ethnographical and Archaeological Papers from the Fifteenth Pacific Science Congress): 119-135, ed. A. Anderson. Pacific Anthropological Records 37. Honolulu: Department of Anthropology, Bishop Museum.

2003 The Lapita horizon and traditions: Signature for one set of Oceanic migrations, in Pacific Archaeology: Assessments and Prospects (Proceedings of the International Conference for the Fiftieth Anniversary of the First Lapita Excavation, Kone-Nouméa 2002): 95-120, ed. C. Sand. Nouméa: Services des Musées et du Patrimoine.

Groube, L.

1971 Tonga, Lapita pottery, and Polynesian origins. Journal of the Polynesian Society 80:278316.

Houghton, P.

1996 People of the Great Ocean: Aspects of Human Biology of the Early Pacific. Cambridge: Cambridge University Press.

Houghton, P., F. Leach, and D. G. Sutton

1975 The estimation of stature of prehistoric Polynesians in New Zealand. Journal of the Polynesian Society $84: 325-336$.

Hunt, T. L.

1980 Towards Fiji's Past: Archaeological Research on South-western Viti Levu. M.A. thesis. University of Auckland, New Zealand.

Katayama, K., P. D. Nunn, R. Kumar, S. Matararaba, and H. Oda

2003 Reconstruction of a Lapita lady skeleton unearthed from the Moturiki Island, Fiji (Preliminary report). Anthropological Science 111:404-405.

KAY, R.M.A.

1984 Analysis of Archaeological Material from Naigani. M.A. thesis, University of Auckland, New Zealand.

KIRCH, P. V.

1988 The Talepakemalai site and Oceanic prehistory. National Geographic Research 4:328-342.

1997 The Lapita Peoples: Ancestors of the Oceanic World. Cambridge, MA, and Oxford: Blackwell.

Kirch, P. V., and R. C. Green

2001 Hawaiki, Ancestral Polynesia: An Essay in Historical Anthropology. New York: Cambridge University Press. 
Kirch, P. V., T. L. Hunt, M. Weisler, V. Butler, and M. S. Allen

1991 Mussau Islands prehistory: Results of the 1985-6 excavations, in Report of the Lapita Homeland Project: 144-163, ed. J. Allen and C. Gosden. Occasional Papers in Prehistory No. 20. Canberra: Department of Prehistory, Australian National University.

KirCh, P. V., AND D. E. Yen

1982 Tikopia: The Prehistory and Ecology of a Polynesian Outlier. Bishop Museum Bulletin No. 238. Honolulu: Bishop Museum Press.

Kumar, R., AND P. D. NUNN

2003 Inland and coastal Lapita settlement on Vitilevu Island, Fiji: New data. Domodomo $16: 15-20$.

Kumar, R., P. D. Nunn, AND W. R. Dickinson

2004a The emerging pattern of earliest human settlement in Fiji: four new Lapita sites on Viti Levu Island. Archaeology in New Zealand 47:108-117.

Kumar, R., P. D. Nunn, K. Katayama, H. Oda, S. Matararaba, and T. Osborne

2004b The earliest-known humans in Fiji and their pottery: The first dates from the 2002 excavations at Naitabale (Naturuku), Moturiki Island. South Pacific Journal of Natural Science $22: 15-21$.

Ladefoged, T. N., J. Wall, P. Black, and W. R. Dickinson

1998 Exotic and indigenous ceramic sherds from the island of Rotuma. Journal of the Polynesian Society 107:301-311.

LEACH, F., AND J. DAVIDSON

2000 Fishing: A neglected aspect of Oceanic economy, in Australian Archaeologist: Collected Papers in Honour of Jim Allen: 412-426, ed. A. Anderson and T. Murray. Canberra: Coombs Academic Publishing, Australian National University.

Leach, F., C. J. Quinn, G. L. Lyon, A. Haystead, and D. B. Myers

2000 Evidence of prehistoric Lapita diet at Watom Island, Papua New Guinea, using stable isotopes. New Zealand Journal of Archaeology 20:149-159.

Leach, F., C. J. Quinn, J. Morrison, and G. Lyon

2003 The use of multiple isotope signatures in reconstructing prehistoric human diet from archaeological bone from the Pacific and New Zealand. New Zealand Journal of Archaeology $23: 31-98$

LEPOFSKY, D.

1988 The environmental context of Lapita settlement locations, in Archaeology of the Lapita Cultural Complex: A Critical Review: 33-47, ed. P. V. Kirch and T. L. Hunt. Seattle: Thomas Burke Memorial Washington State Museum Research Report 5.

Lovejoy, C. O., R. S. Meindl, T. R. Pryzbeck, and R. P. Mensforth

1985 Chronological metamorphosis of the auricular surface of the ilium: A new method for the determination of adult skeletal age at death. American Journal of Physical Anthropology $68: 15-28$.

MADSEN, D. B., AND D. N. SChMitT

1998 Mass collecting and the diet breadth model: A Great Basin example. Journal of Archaeological Science 25 : 445-455.

Meindi, R. S., And C. O. Lovejoy

1985 Ectocranial suture closure: A revised method of the determination of skeletal age at death on the lateral-anterior sutures. American Journal of Physical Anthropology 68:57-66.

NAGAOKA, L.

1988 Lapita subsistence: The evidence of non-fish archaeofaunal remains, in Archaeology of the Lapita Cultural Complex: A Critical Review: 117-133, ed. P. V. Kirch and T. L Hunt. Seattle: Thomas Burke Memorial Washington State Museum Research Report 5.

NASH, W.

1988 The Queensland Trochus Fishery and Management-Related Aspects of Trochus Biology. Noumea: South Pacific Commission.

Nunn, P. D.

1999a Lapita pottery from Moturiki Island, central Fiji. Archaeology in New Zealand 42:309-313.

1999b Early human settlement and the possibility of contemporaneous volcanism, western Kadavu, Fiji. Domodomo 12:36-49. 
2005 Reconstructing tropical paleoshorelines using archaeological data: Examples from the Lapita era in Fiji (southwest Pacific). Journal of Coastal Research (Special Issue) 42:15-25.

Nunn, P. D., R. Kumar, S. Matararaba, T. Ishimura, J. Seeto, S. Rayawa, S. Kuriyawa, A.

Nasila, B. Oloni, A. Rati Ram, P. Saunivalu, P. Singh, and E. Tegu

2004a Early Lapita settlement site at Bourewa, southwest Viti Levu Island, Fiji. Archaeology in Oceania 39: 139-143.

Nunn, P. D., and S. Matararaba

2000 New finds of Lapita pottery in northeast Fiji. Archaeology in Oceania 35:96-97.

Nunn, P. D., S. Matararaba, and F. Areki

2004b A Lapita site on Ovalau Island, central Fiji Islands. Archaeology in New Zealand 47:215219.

Nunn, P. D., S. Matararaba, T. Ishimura, R. Kumar, and E. Nakoro

2005 Reconstructing the Lapita-era geography of northern Fiji: A newly discovered Lapita site on Yadua Island and its implications. New Zealand Journal of Archaeology 26:41-55.

Nunn, P. D., And W. R. Peltier

2001 Far-field test of the ICE-4G (VM2) model of global isostatic response to deglaciation: Empirical and theoretical Holocene sea-level reconstructions for the Fiji Islands, southwest Pacific. Quaternary Research 55:203-214.

PARHAM, J. W.

1972 Plants of the Fiji Islands, revised ed. Suva: Government Printer.

Paulay, G.

2001 Benthic ecology and biota of Tarawa Lagoon: Influence of equatorial upwelling, circulation, and human harvest. Atoll Research Bulletin $487: 1-41$.

Pietrusewsky, M., J.-C. Galipaud, and F. Leach

1998 A skeleton from the Lapita site at Kone, Foue Peninsula, New Caledonia. New Zealand Journal of Archaeology 18:25-74.

Pietrusewsky, M., T. L. Hunt, and R. M. Ikehara-Quebral

1997a A Lapita-associated skeleton from Waya Island. Micronesica 30:355-388.

1997b A new Lapita-associated skeleton from Fiji. Journal of Polynesian Society 106:284-295.

Prag, J., AND R. NeAve

1997 Making Faces: Using Forensic and Archaeological Evidence. London: British Museum Press.

RAAB, L. M.

1992 An optimal foraging analysis of prehistoric shellfish collecting on San Clemente Island, California. Journal of Ethnobiology $12: 63-80$.

Ramoli, A., AND P. D. NunN

2001 Naigani Island and its historical connections with Ovalau and Moturiki Islands: Convergences between legend and fact. Domodomo 13:19-28.

SAND, C.

1997 Lapita-Collection de Poteries du Site de Foué. Nouméa: Les Cahiers de l'Archéologie en Nouvelle-Calédonie 7.

1998 Archaeological report on localities WKO013A and WKO013B at the site of Lapita (Koné, New Caledonia). Journal of the Polynesian Society 107:7-34.

Spennemann, D.H.R.

1987 Availability of shellfish resources on prehistoric Tongatapu: Effects of human predation and changing environment. Archaeology in Oceania 22:81-96.

SPRIGGS, M.

1984 The Lapita cultural complex: Origins, distribution, contemporaries and successors. Journal of Pacific History 19:202-223.

1990 The changing face of Lapita: Transformation of a design, in Lapita Design, Form and Composition: 83-122, ed. M. Spriggs. Occasional Papers in Prehistory No. 19. Canberra: Department of Prehistory, Australian National University.

2002 They've grown accustomed to your face, in Fifty Years in the Field: Essays In Honour and Celebration of Richard Shutler Jr's Archaeological Career: 51-57, ed. S. Bedford, C. Sand, and D. Burley. New Zealand Archaeological Association Monograph 25. Auckland: NZAA.

Summerhayes, G.

2000 Lapita Interaction. Terra Australis 15. Canberra: RSPAS, Australian National University. 
SWAdLING, P.

1986 Lapita shellfishing: Evidence from sites in the Reef/Santa Cruz Group, southeast Solomons, in Traditional Fishing in the Pacific: Ethnographical and Archaeological Papers from the Fifteenth Pacific Science Congress: 137-148, ed. A. Anderson. Pacific Anthropological Records No. 37. Honolulu: Department of Anthropology, B. P. Bishop Museum.

Tebano, T., and G. Paulay

2001 Variable recruitment and changing environments create a fluctuating resource: The biology of Anadara uropigimelana (Bivalvia: Arcidae) on Tarawa Atoll. Atoll Research Bulletin 488: $1-15$.

Thomas, F. R.

2002 An evaluation of central-place foraging among mollusk gatherers in western Kiribati, Micronesia: Linking behavioral ecology with ethnoarchaeology. World Archaeology $34: 182-208$.

Thomas, F. R., P. D. Nunn, T. Osborne, R. Kumar, F. Areki, S. Matararaba, D. Steadman, AND G. HOPE

2004 Recent archaeological findings at Qaranilaca Cave, Vanuabalavu Island, Fiji. Archaeology in Oceania 39: 42-49.

TrotTer, M.

1970 Estimation of stature from intact long limb bones, in Personal Identification in Mass Disaster: 71-83, ed. T. D. Stuart. Washington, DC: National Museum of Natural History.

VISSER, E.

1994 Skeletal evidence of kava use in prehistoric Fiji. Journal of the Polynesian Society 103:299317.

WeLLS, S. M.

1989 Impacts of the precious shell harvest and trade: Conservation of rare or fragile resources, in Marine Invertebrate Fisheries: Their Assessment and Management: 443-454, ed. J. F. Caddy. New York: Wiley.

\section{ABSTRACT}

In 2003 the authors discovered and excavated a Lapita site at Naitabale close to the southern end of Moturiki Island (central Fiji). Today the site is $350 \mathrm{~m}$ inland from the coast, but in Lapita times it was located behind the active beach ridge. A large collection of potsherds (including 92 dentate-stamped or incised Lapita sherds), shell, and animal bones was recovered, together with a human burial. Sherd decorations show affinities with the Western Lapita Province rather than the Eastern Lapita Province (which includes Fiji). Temper analyses of 45 Lapita sherds do not show any unmistakably exotic (to Fiji) pottery, but 29 percent are nonlocal to Moturiki and nearby islands. Fish bones are mostly from inshore species (dominated by Scaridae), while nonfish vertebrates are dominated by turtle and include dog and chicken. Shellfish remains are dominated by gastropods, mostly Strombus spp. (43 percent of gastropod MNI). The surf clam (Atactodea striata) accounts for 38 percent of bivalve MNI, with Anadara antiquata and Gafrarium pectinatum each representing 14 percent of the bivalve MNI. The skeleton is that of a woman (Mana) 161-164 $\mathrm{cm}$ tall who died at 40-60 years of age. Six radiocarbon dates from bones overlap 2740-2739 cal. years B.P. (790-789 B.c.). The mandible lacks antegonial notches but is not a proper rocker jaw. The cranium was better preserved than any Lapitaassociated skeleton hitherto described, which allowed the head to be reconstructed. Stable-isotope analyses show that her diet contained significant amounts of reef foods but was probably dominated by terrestrial plants. The Lapita occupation of Naitabale is likely to have begun by 2850 cal. years B.P. (900 B.C.). Radiocarbon dates and pottery decorative styles both suggest Naitabale was first occupied within the early part of the Lapita history of Fiji. KEYwORDs: Fiji, Lapita, pottery, pottery temper, fish, turtle, shellfish, human, dating. 